Key Words:

Blend Ratio

Solids

Retention: Permanent

Key WTP R\&T References:

Test Specification:

24590-WTP-TSP-RT-02-007, Rev. 0

Test Plan: WSRC-TR-2002-00463, Rev. 0

SRT-RPP-2002-00223

Test Exceptions: N/A

R\&T Focus Area: Pretreatment

Test Scoping Statement(s): S-70

BCR No. 03-04, March 27, 2003

\title{
EVAPORATION OF PRETREATED HANFORD TANK AW-101 SAMPLE MIXED WITH RECYCLE
}

\author{
Mark L. Crowder, 773-A, SRTC, SRS \\ Charles L. Crawford, 773-41A, SRTC, SRS \\ Erich K. Hansen, 999-W, SRTC, SRS \\ Fernando Fondeur, 773-A, SRTC, SRS
}

OCTOBER 2003

Westinghouse Savannah River Company

Savannah River Site

Aiken, SC 29808

Prepared for the U.S. Department of Energy Under Contract Number DE-AC09-96SR18500

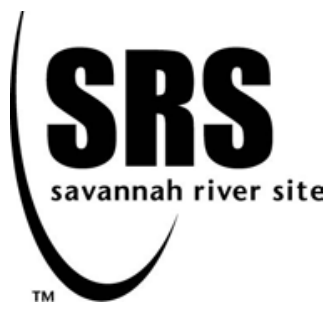


This document was prepared in conjunction with work accomplished under Contract No. DE-AC09-96SR18500 with the U. S. Department of Energy.

\section{DISCLAIMER}

This report was prepared as an account of work sponsored by an agency of the United States Government. Neither the United States Government nor any agency thereof, nor any of their employees, makes any warranty, express or implied, or assumes any legal liability or responsibility for the accuracy, completeness, or usefulness of any information, apparatus, product or process disclosed, or represents that its use would not infringe privately owned rights. Reference herein to any specific commercial product, process or service by trade name, trademark, manufacturer, or otherwise does not necessarily constitute or imply its endorsement, recommendation, or favoring by the United States Government or any agency thereof. The views and opinions of authors expressed herein do not necessarily state or reflect those of the United States Government or any agency thereof.

This report has been reproduced directly from the best available copy.

Available for sale to the public, in paper, from: U.S. Department of Commerce, National Technical Information Service, 5285 Port Royal Road, Springfield, VA 22161, phone: (800) 553-6847, fax: (703) 605-6900

email: orders@ntis.fedworld.gov

online ordering: http://www.ntis.gov/help/index.asp

Available electronically at http://www.osti.gov/bridge

Available for a processing fee to U.S. Department of Energy and its contractors, in paper, from: U.S. Department of Energy, Office of Scientific and Technical Information, P.O. Box 62, Oak Ridge, TN 37831-0062,

phone: (865)576-8401,

fax: (865)576-5728

email: $\underline{\text { reports@ adonis.osti.gov }}$ 
WSRC-TR-2003-00218, REVISION 0

SRT-RPP-2003-00156, REVISION 0

\section{TABLE OF CONTENTS}

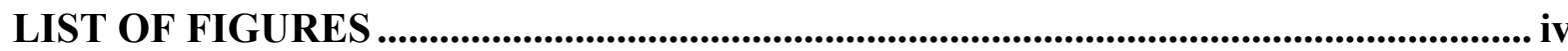

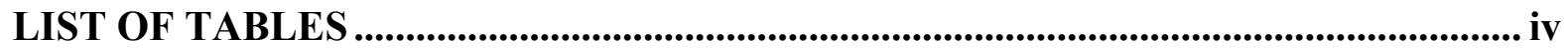

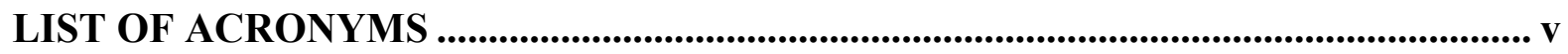

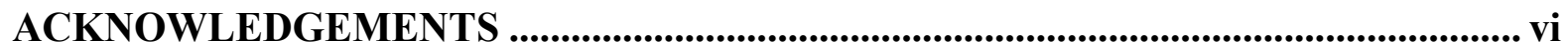

1.0 SUMMARY OF TESTING .......................................................................................... 1

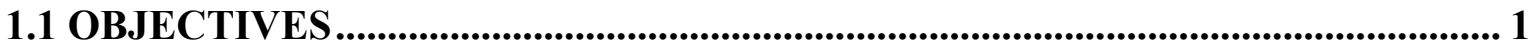

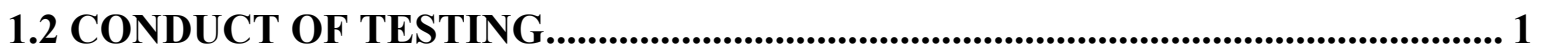

1.3 RESULTS AND PERFORMANCE AGAINST OBJECTIVES ............................ 1

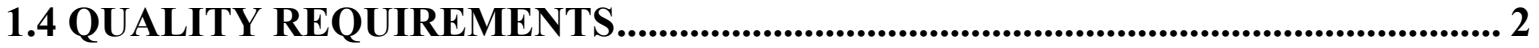

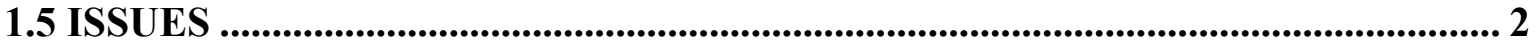

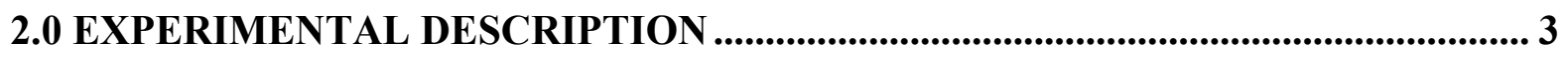

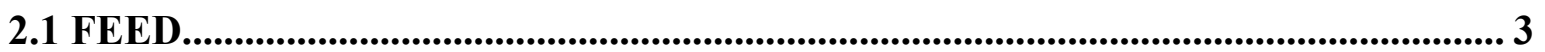

2.2 SYSTEM CONFIGURATION ........................................................................................ 7

3.0 RESULTS AND DISCUSSION ..................................................................................... 9

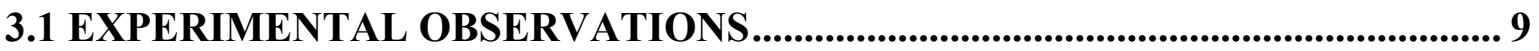

3.1.1 Blend Ratio: 45:55 ................................................................................... 9

3.1.2 Blend Ratio: 35:65 ............................................................................................ 11

3.2 BOILING POINT ................................................................................................................... 12

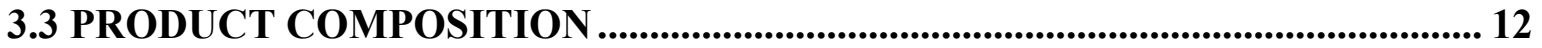

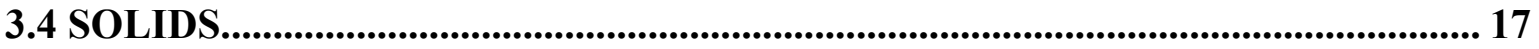

3.5 RHEOLOGY ................................................................................................... 19

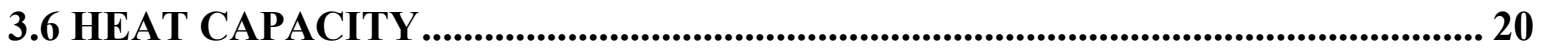

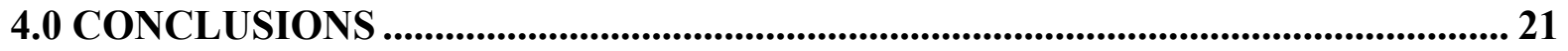

5.0 FUTURE WORK ......................................................................................................... 23

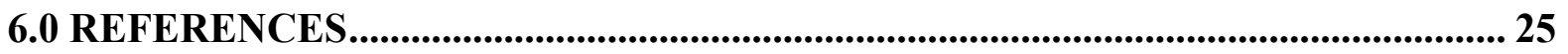

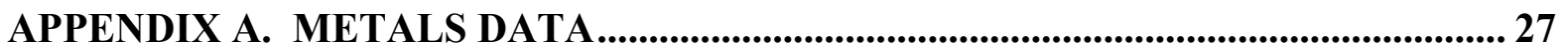




\section{LIST OF FIGURES}

Figure 1. Settled (left) and mixed solutions of SBS A2 simulant recycle ............................... 6

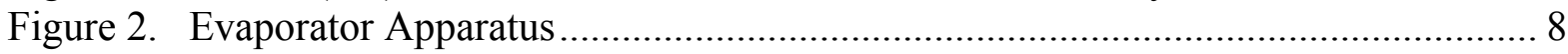

Figure 3. Operating conditions for evaporation of 45:55 blend of AW101/SBS A2 …......... 9

Figure 4. Photographs of Evaporator Operation ........................................................... 10

Figure 5. Operating conditions for evaporation of 35:65 blend of AW101/SBS A2 …....... 11

Figure 6. Experimental and model boiling points for 35:65 blend of AW101/SBS A2 …... 12

Figure 7. Wt. \% Total and Insoluble Solids for 35:65 Blend of AW-101/SBS A2 ….......... 18

Figure 8. Flow Curve for 45:55 Blend of AW-101 to SBS A2 at 7 M sodium .................... 19

\section{LIST OF TABLES}

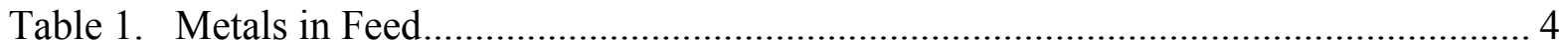

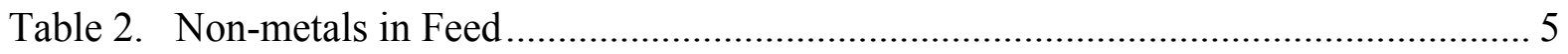

Table 3. Products from Evaporation of 45:55 Blend (AW-101:SBS A2) …………............ 13

Table 4. Anions and Other Evaporation Products of the 45:55 Blend................................. 14

Table 5. Radioactive and Trace Metal Components in Evaporation of 45:55 Blend ........... 15

Table 6. Products from Evaporation of 35:65 Blend (AW-101:SBS A2) ........................... 16

Table 7. More Products of Evaporation of 35:65 Blend .................................................... 17

Table 8. Solids and Sodium Concentrations during Evaporation of 35:65 Blend ................. 18

Table 9. Solids and Sodium Concentrations during Evaporation of 45:55 Blend ................. 18 
WSRC-TR-2003-00218, REVISION 0

SRT-RPP-2003-00156, REVISION 0

\section{LIST OF ACRONYMS}

$\begin{array}{ll}\text { ICP } & \text { Inductively Coupled Plasma } \\ \text { LAW } & \text { Low Activity Waste } \\ \text { NIST } & \text { National Institute of Standards and Technology } \\ \text { NM } & \text { Not Measured } \\ \text { QA } & \text { Quality Assurance } \\ \text { RPP } & \text { River Protection Project } \\ \text { SBS } & \text { Submerged Bed Scrubber } \\ \text { SRTC } & \text { Savannah River Technology Center } \\ \text { St. Dev. } & \text { Standard Deviation } \\ \text { Toc } & \text { Total Organic Carbon } \\ \text { WTP } & \text { Waste Treatment Plant } \\ \text { XRD } & \text { X-ray Diffraction }\end{array}$


WSRC-TR-2003-00218, REVISION 0

SRT-RPP-2003-00156, REVISION 0

\section{ACKNOWLEDGEMENTS}

The authors thank the following personnel for their excellent contributions:

Mike Lee, lead technician, and Sarah Brown, for laboratory assistance; Mark Baich for designing the rig and Gary Dobos from the SRTC Glass Shop for making it; the Analytical Development Section for many analyses; Gene Daniel for OLI modeling calculations; Phyllis Burkhalter for heat capacity determinations; and Mimi Jones for technical editing. 


\subsection{SUMMARY OF TESTING}

\subsection{OBJECTIVES}

This task was undertaken to provide validation data for the Treated Feed Evaporator flowsheet and operating conditions using Hanford Tank 241-AW-101 (Envelope A) pretreated waste blended with simulated River Protection Project Waste Treatment Plant (RPP-WTP) waste recycles. This radioactive task provided the first opportunity to compare performance of blended actual treated waste to the performance of blended treated waste simulants and recycle simulants. ${ }^{1}$ Specific objectives were:

1) determining the effect of plant recycles

2) developing solubility data, as well as chemical and physical property data

3) evaluating antifoam effectiveness

These were all accomplished except for antifoam evaluation since foaming did not occur during the majority of evaporation testing. Foaming was only observed well past saturation for one of the blends.

\subsection{CONDUCT OF TESTING}

The treated AW-101 sample was produced from the composite effluent of Ion Exchange testing carried out at SRTC. ${ }^{2}$ Submerged Bed Scrubber (SBS) Recycle (subenvelope A2) was made by Duratek during vitrification melter tests with simulants. These feed streams were blended at two different ratios, 45:55 and 35:65 AW-101 to SBS A2, corresponding to the baseline flowsheet ratio of 40:60. ${ }^{3}$ SRTC personnel characterized the feed materials, the blended feed mixtures, and the evaporation products.

A 4-inch ID evaporator was used to concentrate 3-5 L of each blend ${ }^{4}$ to the target RPP-WTP design concentration of $8 \mathrm{M} \mathrm{Na}$. Plant design pressure $(\sim 60 \mathrm{~mm} \mathrm{Hg})$ and temperature $\left(\sim 50-60^{\circ} \mathrm{C}\right)$ were used. The evaporator produced $4 \mathrm{ml} / \mathrm{min}$ of condensate, which converts to $0.012 \mathrm{gpm} / \mathrm{ft}^{2}$, or $4 \%$ of the maximum RPP-WTP design flux. ${ }^{5}$ Samples were taken at nominally $5 \mathrm{M} \mathrm{Na}, 8 \mathrm{M} \mathrm{Na}$, and $11 \mathrm{M} \mathrm{Na}$ (i.e., saturation).

\subsection{RESULTS AND PERFORMANCE AGAINST OBJECTIVES}

The design basis operating conditions were validated. The evaporator operated at $60 \mathrm{~mm} \mathrm{Hg}$, and boiling temperature increased from $45^{\circ} \mathrm{C}$ for the dilute solution to $52^{\circ} \mathrm{C}$ (or $59^{\circ} \mathrm{C}$ at $80 \mathrm{~mm} \mathrm{Hg}$ ) for the target concentration of $8 \mathrm{M} \mathrm{Na}$. Precipitation began between 8.7 and 10.4 M Na. Chemical and physical property data were developed for the AW-101 ion exchange effluent, the SBS A2 simulant recycle, two blends (45:55 and 35:65) of AW-101 to SBS A2, as well as condensate and concentrate solutions. Analyses included solids characterization. 
During these evaporation tests, no excessive or problematic solids formed. Therefore, it is unlikely that solids will be an issue for evaporation of AW-101 material with recycle in the LAW portion of the RPP-WTP. In general, foaming did not occur. However, foaming was observed during post-saturation boiling of the 45:55 blend of AW-101 and SBS A2. (The post-saturation concentrate included $10.4 \mathrm{M} \mathrm{Na}, 59 \mathrm{wt} . \%$ total solids, and $5.7 \mathrm{wt} . \%$ suspended solids.) Foaming was not observed for the 35:65 blend, even after saturation (i.e., 11.0 M Na, 10.4 wt.\% suspended solids, and 59 wt.\% total solids).

Concentrated solutions of AW-101/SBS A2 at 7.0 and 7.6 M Na had viscosity values of $7-9 \mathrm{cP}$ and a heat capacity of $0.8 \mathrm{cal} / \mathrm{g}{ }^{\circ} \mathrm{C}$. These values for actual $\mathrm{AW}-101$ solutions were significantly higher than those of Envelope A simulants in an earlier study. ${ }^{1}$ These differences are due in part to the fact that the simulants were not made to match specific tanks, such as AW-101. Also, the radioactive AW-101 samples were evaluated on different instruments than the non-radioactive simulants, with experimental error of $10 \%$ assumed for each instrument. It is important to note that the viscosities of concentrated AW-101 solutions in this study, as well as those of the simulants in the earlier study, all fall well within the expected range of 0.4 to $15 \mathrm{cP}$, the current bounding conditions for the WTP. ${ }^{6}$

\subsection{QUALITY REQUIREMENTS}

This work was conducted in accordance with the RPP-WTP QA requirements specified for work conducted by SRTC as identified in DOE IWO M0SRLE60. SRTC has provided matrices to WTP demonstrating compliance of the SRTC QA program with the requirements specified by WTP. Specific information regarding the compliance of the SRTC QA program with RW-0333P, Revision 10, NQA-1 1989, Part 1, Basic and Supplementary Requirements and NQA-2a 1990, Subpart 2.7 is contained in these matrices. As noted in the Test Specification, ${ }^{5} \mathrm{DOE} / \mathrm{RW}-033 \mathrm{P}$ is not applicable to this work. The specific QA requirements associated with this task are outlined in a Task Technical and Quality Assurance Plan. ${ }^{8}$

\subsection{ISSUES}

These tests did not raise issues for the design and operation of the RPP-WTP. However, experimental vapor flux was only $4 \%$ of the maximum design flux. Because higher fluxes were not tested, a foaming issue during evaporation of this material in the RPP-WTP cannot be completely ruled out. Higher fluxes will be tested on a pretreated sample from tank AN-104. 
WSRC-TR-2003-00218, REVISION 0

SRT-RPP-2003-00156, REVISION 0

\subsection{EXPERIMENTAL DESCRIPTION}

\subsection{FEED}

The key portion of the evaporator feed originated from Hanford Tank 241-AW-101. This tank is in Envelope A, subset A2 of the tanks to be treated by the RPP-WTP. The AW-101 sample was diluted, characterized, and treated for cesium and technetium removal by ion exchange at SRTC. (Pretreatment of AW-101 by ion exchange at SRTC occurred prior to the removal of technetium treatment from the flowsheet.) The resulting pretreated AW-101 sample was used for these experiments, and was blended with a simulated recycle stream, SBS A2, generated by Duratek. SBS stands for Submerged Bed Scrubber, a processing step in the RPP-WTP Low Activity Waste (LAW) vitrification process. Hence, the SBS material contains glass-former solids. A2 is the subenvelope designation for a particular Duratek processing run. Previously, the SBS A2 sample has also been identified as RM-02-163.

The major components of the feed are shown in Table 1 and Table 2. In most cases, these values represent the average of two samples. Radioactive components are in the Results section (Table 5) for comparison with evaporator products. For SBS A2 and the blended solutions, samples were filtered prior to analysis, except for specific gravity and percent solids determinations.

The AW-101 portion of the feed contained $4.76 \mathrm{M}$ sodium (Na), and the SBS A2 portion of the feed contained only $0.12 \mathrm{M} \mathrm{Na}$. Evaporator runs were conducted with two different blends of AW-101 to SBS A2, 45:55 and 35:65. These ratios were chosen in light of the 40:60 blend ratio expected in the RPP-WTP. ${ }^{3}$

In Table 1, almost all measured concentrations in the blended feeds are close to the expected values based on concentrations in the AW-101 and SBS A2 solutions. However, a few blend concentrations indicate a discrepancy. For silicon (Si), calcium $(\mathrm{Ca})$, and zinc $(\mathrm{Zn})$, concentrations in the blends are higher than expected. This is likely due to partial dissolution (after blending) of some of the solids present in SBS A2. Si and Ca were the most predominant elements identified in SBS A2 solids, as discussed later in this section. $\mathrm{Si}, \mathrm{Ca}$, and $\mathrm{Zn}$ were all present in sufficient quantity in the SBS A2 solids that partial dissolution in the caustic blend matrix would yield the measured increases in dissolved concentration. Other elements in Table 1 which were present in trace quantities did not show a suitable mass balance before and after blending. It is likely that the chemical changes due to blending caused shifts in the equilibrium concentrations of these trace species. On the whole, the reported concentrations in Table 1 and Appendix A, which includes many analyses of evaporator product solutions, show consistent behavior for a wide range of elements. 
WSRC-TR-2003-00218, REVISION 0

SRT-RPP-2003-00156, REVISION 0

Table 1. Metals in Feed

\begin{tabular}{|c|c|c|c|c|}
\hline & $\begin{array}{c}\text { AW101 IX Effl. } \\
\text { mg/L }\end{array}$ & $\begin{array}{c}\text { SBS A2 Recycle } \\
\mathrm{mg} / \mathrm{L}\end{array}$ & $\begin{array}{c}\text { Blend 45:55 } \\
\mathrm{mg} / \mathrm{L}\end{array}$ & $\begin{array}{c}\text { Blend 35:65 } \\
\mathrm{mg} / \mathrm{L}\end{array}$ \\
\hline \multicolumn{5}{|c|}{ ICP-Emission Spectrometry } \\
\hline $\mathrm{Ag}$ & 0.27 & 1.03 & $<0.16$ & $<0.16$ \\
\hline $\mathrm{Al}$ & 12950 & 0.86 & 5910 & 4060 \\
\hline B & 15.8 & 838 & 449 & 530 \\
\hline $\mathrm{Ba}$ & 0.42 & $<0.02$ & $<0.38$ & $<0.38$ \\
\hline $\mathrm{Ca}$ & 4.11 & 0.53 & 4.27 & 5.23 \\
\hline $\mathrm{Cd}$ & 1.03 & $<0.03$ & 0.086 & $<0.08$ \\
\hline $\mathrm{Ce}$ & 3.67 & $<1.5$ & 1.08 & 2.56 \\
\hline $\mathrm{Cr}$ & 39.6 & 40.7 & 39.4 & 40.1 \\
\hline $\mathrm{Cu}$ & 2.41 & $<0.1$ & 0.71 & 0.54 \\
\hline $\mathrm{Fe}$ & 1.72 & $<0.09$ & 0.48 & 0.14 \\
\hline $\mathrm{Gd}$ & $<0.47$ & NM & $<0.47$ & $<0.47$ \\
\hline $\mathrm{K}$ & 19150 & 1117 & 9250 & 6080 \\
\hline $\mathrm{La}$ & 0.51 & $<1.4$ & $<0.14$ & 0.46 \\
\hline $\mathrm{Li}$ & $<0.86$ & 1.49 & $<0.86$ & 1.44 \\
\hline $\mathrm{Mg}$ & $<0.11$ & 0.88 & $<0.11$ & $<0.11$ \\
\hline $\mathrm{Mn}$ & $<0.02$ & 0.03 & $<0.02$ & $<0.02$ \\
\hline Mo & 38 & 0.2 & 17.3 & 9.32 \\
\hline $\mathrm{Na}$ & 109000 & 2761 & 50550 & 46400 \\
\hline $\mathrm{Na}(\mathrm{M})$ & 4.76 & 0.12 & 2.21 & 2.02 \\
\hline $\mathrm{Ni}$ & 2.29 & $<0.12$ & 1.06 & 1.33 \\
\hline $\mathrm{P}$ & 143 & $<1.4$ & 61.6 & 48.1 \\
\hline $\mathrm{Pb}$ & 18.2 & $<1.4$ & 2.16 & $<0.67$ \\
\hline $\mathrm{S}$ & 199 & 237 & 226 & 218 \\
\hline $\mathrm{Sb}$ & 35.7 & NM & 15.3 & 12.0 \\
\hline $\mathrm{Si}$ & 63.9 & 49.3 & 84.8 & 72.2 \\
\hline $\mathrm{Sn}$ & 64 & $<0.52$ & 30.5 & 23.3 \\
\hline $\mathrm{Sr}$ & 1.41 & 0.01 & 1.05 & 1.35 \\
\hline Ti & $<0.15$ & $<0.28$ & $<0.15$ & $<0.15$ \\
\hline $\mathrm{U}$ & $<4.54$ & NM & $<4.5$ & 5.47 \\
\hline V & 0.10 & 0.47 & $<0.04$ & NM \\
\hline $\mathrm{Zn}$ & 4.39 & 3.96 & 30.5 & 34.2 \\
\hline $\mathrm{Zr}$ & 5.34 & $<0.10$ & $<0.46$ & $<0.46$ \\
\hline \multicolumn{5}{|c|}{ Atomic Absorption } \\
\hline $\mathrm{Na}$ & NM & 2770 & NM & NM \\
\hline
\end{tabular}

$\mathrm{NM}=$ Not Measured 
WSRC-TR-2003-00218, REVISION 0

SRT-RPP-2003-00156, REVISION 0

Table 2. Non-metals in Feed

\begin{tabular}{|c|c|c|c|c|}
\hline & $\begin{array}{c}\text { AW101 IX } \\
\text { Effluent } \\
\text { mg/L }\end{array}$ & $\begin{array}{c}\text { SBS A2 Recycle } \\
\mathrm{mg} / \mathrm{L}\end{array}$ & $\begin{array}{c}\text { Blend 45:55 } \\
\mathrm{mg} / \mathrm{L}\end{array}$ & $\begin{array}{c}\text { Blend 35:65 } \\
\mathrm{mg} / \mathrm{L}\end{array}$ \\
\hline \multicolumn{5}{|l|}{ IC Anions } \\
\hline Chloride & 1980 & 1850 & 2020 & 1840 \\
\hline Fluoride & 275 & 1090 & 382 & 744 \\
\hline Formate & 1020 & 100 & 607 & 323 \\
\hline Nitrate & 92100 & 1630 & 36700 & 25000 \\
\hline Nitrite & 45200 & 4710 & 22800 & 16200 \\
\hline Oxalate & 226 & 19 & 131 & 86 \\
\hline Phosphate & 154 & $<10$ & 66 & 96 \\
\hline Sulfate & 172 & 864 & 429 & 400 \\
\hline Total Carbon & 2300 & 377 & 1250 & NM \\
\hline Organic Carbon & 878 & 356 & 822 & NM \\
\hline \multirow[t]{2}{*}{ Inorganic Carbon } & 1420 & 21 & 418 & NM \\
\hline & Mol/L & Mol/L & Mol/L & Mol/L \\
\hline Total Base & 2.81 & $\mathrm{NM}$ & 1.25 & 0.888 \\
\hline Free $\mathrm{OH}$ & 2.02 & NM & 0.858 & 0.584 \\
\hline $\begin{array}{l}\text { Other Base } \\
\quad \text { excl. } \mathrm{CO}_{3}\end{array}$ & 0.66 & NM & 0.375 & 0.155 \\
\hline Carbonate & NM & NM & 0.043 & NM \\
\hline $\mathrm{pH}$ & $\mathrm{NM}$ & 7 & NM & $\mathrm{NM}$ \\
\hline Specific Gravity & $1.23^{9}$ & 1.013 & 1.095 & 1.08 \\
\hline & wt.\% & wt.\% & wt.\% & wt.\% \\
\hline Suspended Solids & None visible & 0.42 & 0.20 & 0.39 \\
\hline Total Solids & $32.0^{9}$ & 1.64 & 15.7 & 11.8 \\
\hline
\end{tabular}

$\mathrm{NM}=$ Not Measured 
For AW-101 Ion Exchange Effluent, simulated SBS A2 recycle, blended feeds, and concentrate, the filtrate was clear yellow and the filtered solids were brown. Photographs of both settled and mixed SBS A2 are shown in Figure 1.
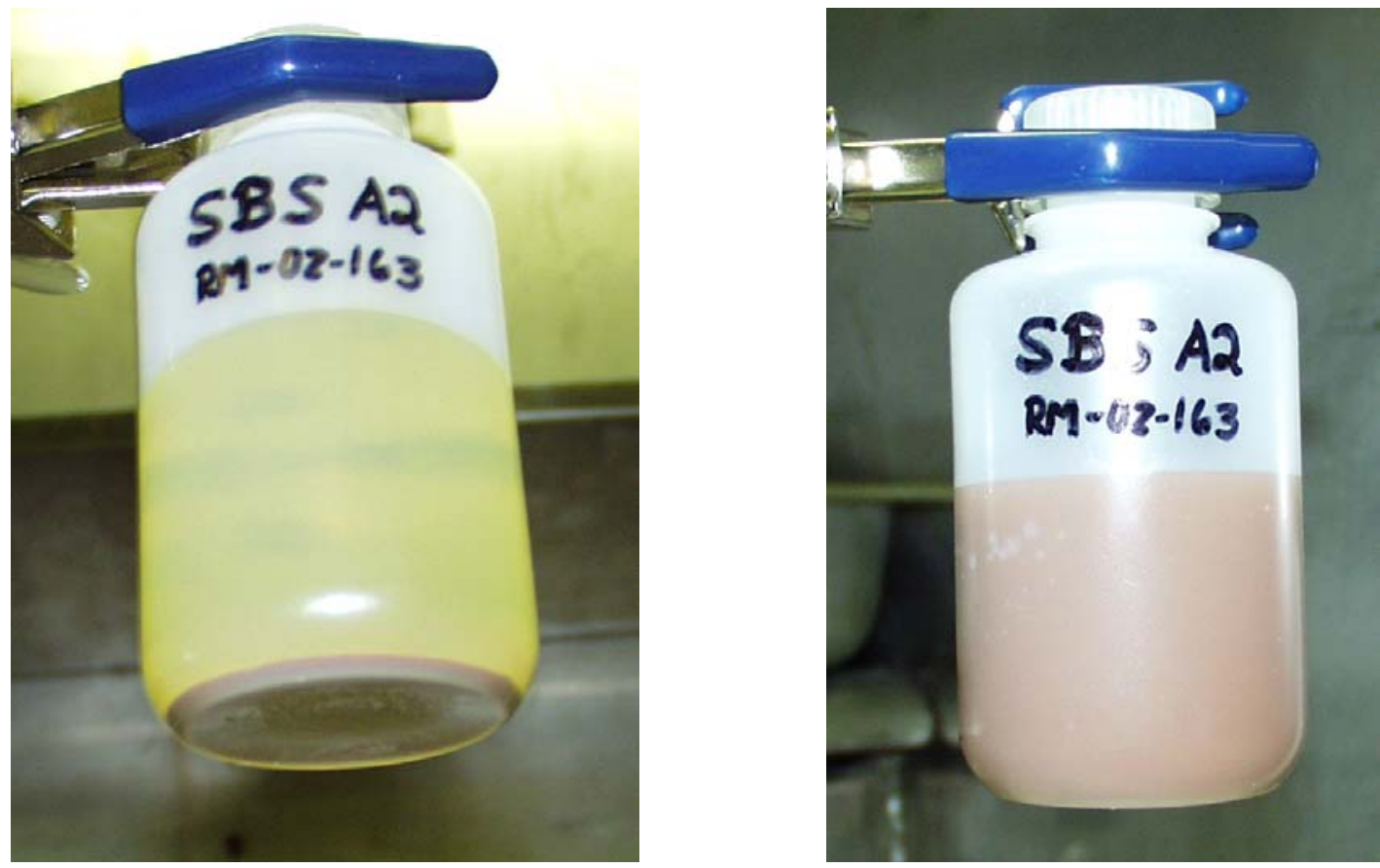

Figure 1. Settled (left) and mixed solutions of SBS A2 simulant recycle

The AW-101 portion of the feed contained no observable solids and, as shown in Table 2, SBS A2 had 0.4 wt. \% suspended or insoluble solids. The crystal structures of SBS A2 solids were identified by x-ray diffraction (XRD) as $\mathrm{SiO}_{2}$ (quartz), $\mathrm{Fe}_{2} \mathrm{O}_{3}, \mathrm{ZrSiO}_{4}, \mathrm{~K}_{2} \mathrm{NaAlF}_{6}$, $\mathrm{TiO}_{2}$, and $\mathrm{CaF}_{2}$. $\mathrm{SiO}_{2}, \mathrm{Fe}_{2} \mathrm{O}_{3}$, and $\mathrm{TiO}_{2}$ are glass formers that were entrained in the Duratek melter offgas. The $\mathrm{ZrSiO}_{4}, \mathrm{CaF}_{2}$, and $\mathrm{K}_{2} \mathrm{NaAlF}_{6}$ are likely to be precipitation products when the offgas was contacted with water in the submerged bed scrubber. It should be noted that $\mathrm{CaF}_{2}$ is only sparingly soluble in water, and not appreciably more soluble in caustic solution.

Attempts to completely dissolve these SBS A2 solids in hot nitric acid or hot sodium hydroxide for further analysis were unsuccessful. However, a fusion (digestion) technique using cesium hydroxide and hydrochloric acid did dissolve the solids. Analysis of the resulting digested solution provided quantitative results on their relative abundance: silicon (11 wt. \% of dry solids), calcium (9.4\%), zirconium (8.7\%), potassium $(6.5 \%)$, iron (4.2\%), aluminum $(4.2 \%)$, sodium $(3.2 \%)$, zinc $(2.2 \%)$, titanium $(1.9 \%)$, magnesium $(1.8 \%)$, chromium $(0.6 \%)$, sulfur $(0.2 \%)$, and other trace components. 


\section{WSRC-TR-2003-00218, REVISION 0 \\ SRT-RPP-2003-00156, REVISION 0}

\subsection{SYSTEM CONFIGURATION}

A photograph of the experimental setup is included in Figure 2. The evaporator, condensers, and condensate collection vessels were fabricated in the SRTC Glass Shop. The evaporator is a 4-in. diameter, 19-in. tall vessel with a volume of $2200 \mathrm{~mL}$. The main evaporator body is quartz, and the lid with multiple entry ports is borosilicate glass. Heat was supplied through a Corning stirrer/hot plate. Feed was drawn into the evaporator by the vacuum in the system and was added periodically to maintain a liquid level between 700 and $1500 \mathrm{~mL}$. The liquid level dropped below this range at the end of each experiment.

The evaporator temperature was monitored using a Cole-Parmer Type K thermocouple and thermocouple readout (model 91100-50). The evaporator pressure was measured using a calibrated SPER Scientific pressure transducer (model PS100) and readout (model 840065). All equipment used to measure temperature and pressure were calibrated with NISTtraceable standards prior to use by the Savannah River Standards Laboratory and logged as Measuring and Test Equipment (M\&TE). Vacuum is pulled on the system using a Vacuubrand MZ 2C Pump, a Teflon ${ }^{\circledR}$ diaphragm pump. The tubing between the evaporator and the vacuum pump was equipped with an air bleed valve to control evaporator pressure.

The two jacketed condensers used were approximately 3 in. diameter, and were cooled using a Neslab Coolflow DC-25 chiller, operated at nominally $18^{\circ} \mathrm{C}$. The first condensate collection vessel had graduations up to $3250 \mathrm{~mL}$. The second condensate vessel was only $250 \mathrm{~mL}$.

Many samples of feed and concentrate required filtering for analysis of the filtrate and/or the solids. Small samples were filtered using Gelman Acrodisc $25 \mathrm{~mm}$ syringe filters with $0.45 \mu \mathrm{m}$ Versapor Membrane. Large samples and all samples requiring solids analysis were vacuum-filtered using Nalgene cellulose nitrate filters, $47 \mathrm{~mm}$ diameter, $0.45 \mu \mathrm{m}$ pore diameter.

The evaporator concentrate samples taken at approximately $8 \mathrm{M} \mathrm{Na}$ were in duplicate. A portion of each sample was submitted for density, suspended solids, and total solids, and another portion was filtered. The filtrate was analyzed for cations (ICPES), anions (IC), hydroxide/base content, and carbon content. In addition, solids were analyzed using x-ray diffraction (XRD) and, in some cases, scanning electron microscopy (SEM). 
WSRC-TR-2003-00218, REVISION 0

SRT-RPP-2003-00156, REVISION 0

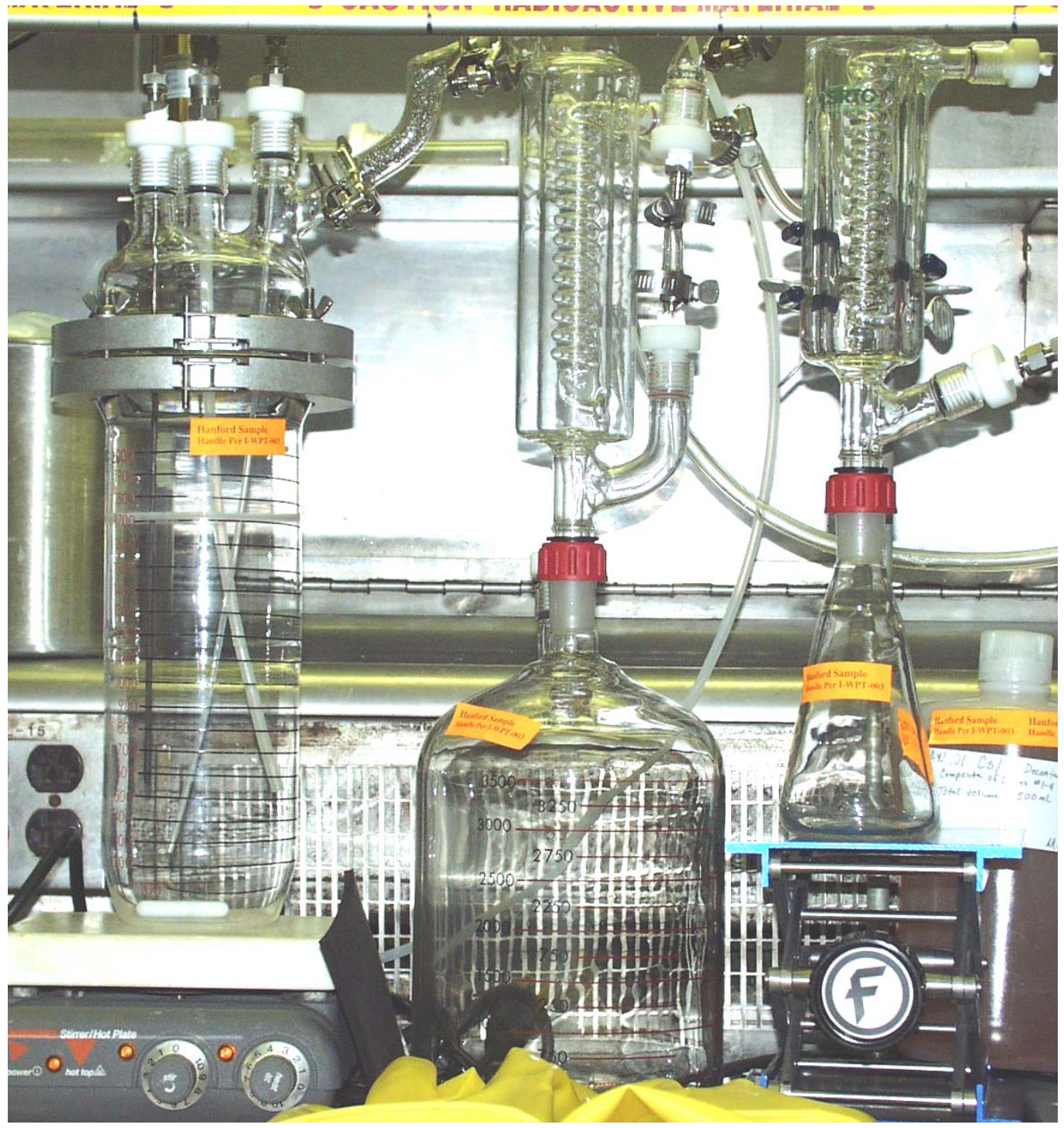

Figure 2. Evaporator Apparatus 


\subsection{RESULTS AND DISCUSSION}

\subsection{EXPERIMENTAL OBSERVATIONS}

\subsubsection{Blend Ratio: 45:55}

In the first experiment, a 45:55 blend of AW-101 to SBS A2 was used as feed (i.e., 1.5 L of treated AW-101 and 1.8 L of SBS A2). The evaporator was charged with $1000 \mathrm{~mL}$ of feed. The hot plate was turned on and gradually increased to full power. Pressure was maintained via a bleed valve at $27.55+/-0.2$ in $\mathrm{Hg}$ vacuum (i.e., $60+/-5 \mathrm{~mm} \mathrm{Hg}$ absolute). During testing, condensate was collected at nominally $4 \mathrm{~mL} / \mathrm{min}$. Only one drop of condensate was observed/collected in the secondary $(250 \mathrm{~mL})$ flask. A plot of the temperature and pressure of the evaporator is shown in Figure 3. Initial rises in temperature were due to startup. Day 3 behavior differed because the bleed valve allowed a consistent, gradual rise in pressure.

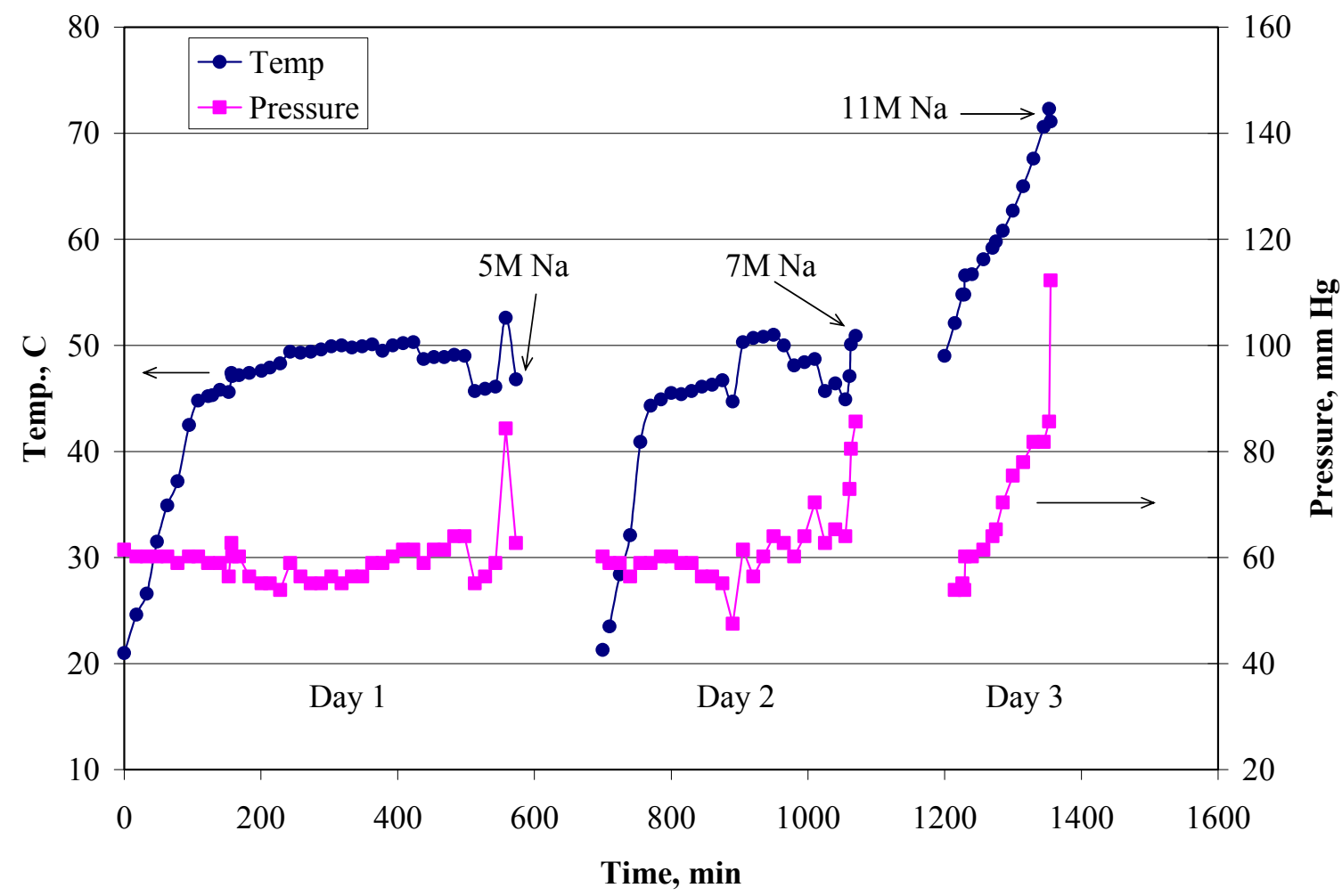

Figure 3. Operating conditions for evaporation of 45:55 blend of AW101/SBS A2

At the end of each day, boiling point data were collected. The system pressure was sequentially increased from approximately 60 to 70 to $80 \mathrm{~mm} \mathrm{Hg}$. At each pressure reading the system temperature was allowed to stabilize during boiling to determine the boiling point. The system was then allowed to cool and samples were taken to determine exact concentrations. 
After the concentration in the evaporator passed $8 \mathrm{M} \mathrm{Na}$, experimenters watched closely to identify a precipitation event. However, no dramatic increases in solids content were observed. Toward the end of the evaporation, the pressure gradually increased in the vessel and the boiling temperature also increased. (The bleed valve may have been open slightly too much.) Foaming was also observed at the end of the evaporation, as shown in Figure 4, with the foam height reaching 2 to 4 times the liquid height. As determined later and shown in Table 9 , foaming occurred at a concentration of $10.4 \mathrm{M} \mathrm{Na}, 59 \mathrm{wt}$. \% total solids, and 5.7 wt. \% suspended solids.
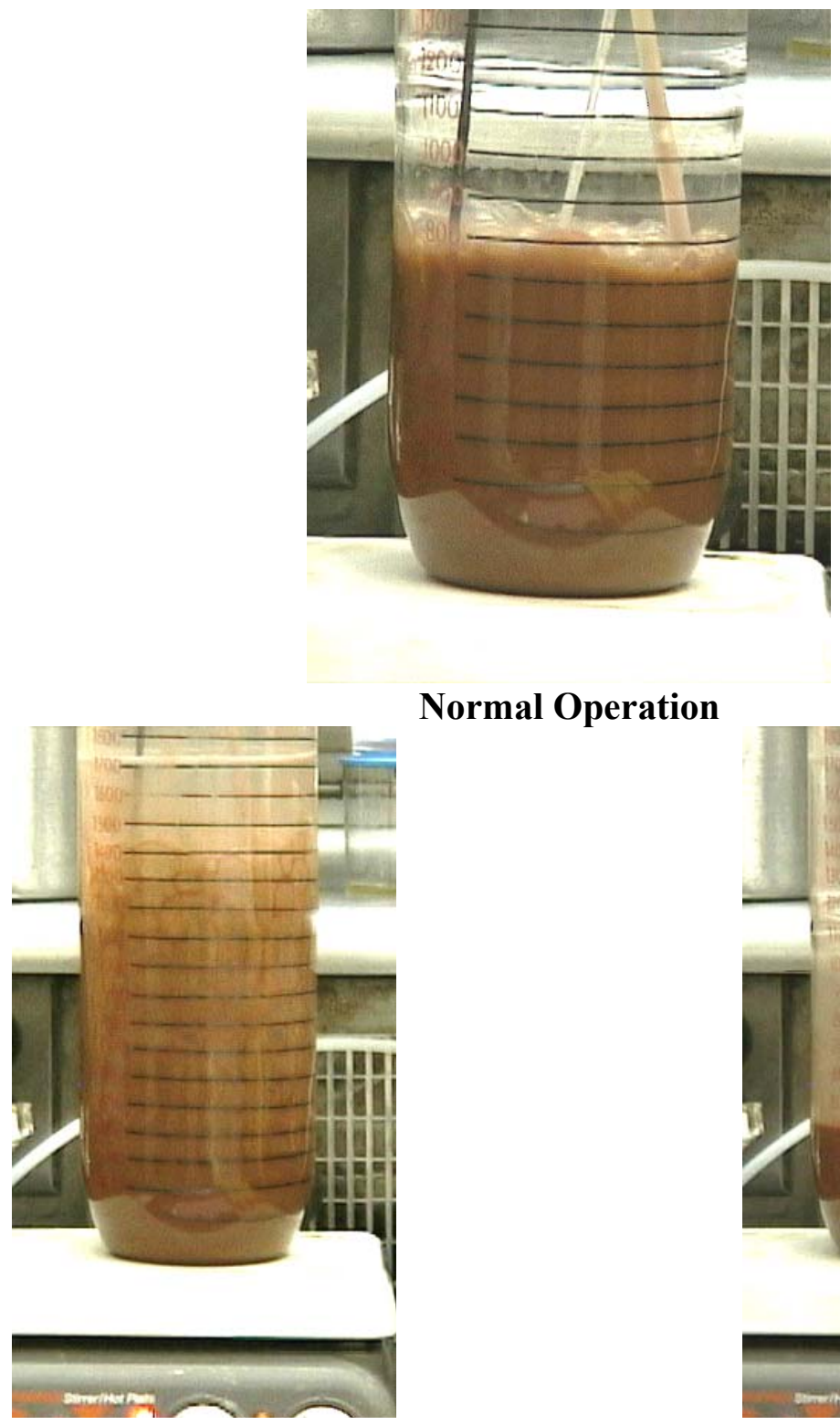

Normal Operation

Post-Saturation Foaming

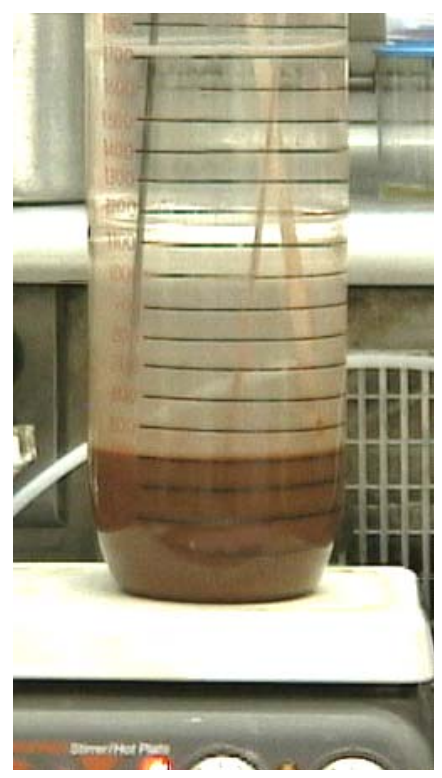

Liquid Level During Foaming

Figure 4. Photographs of Evaporator Operation 


\subsubsection{Blend Ratio: 35:65}

The second experiment involved a 35:65 blend of AW-101 to SBS A2 (i.e., 1.5 L of treated AW-101 and 2.79 L of SBS A2). The experimental method and sampling schedule were the same as the previous evaporation of a 45:55 blend. However, no foaming was observed, even after the concentrate was well past saturation. The evaporator operating conditions for this blended sample is in Figure 5. Sharp drops in temperature in Figure 5 were due to either feed additions or brief suspensions in heating for sampling purposes. Pressure changes were made for boiling point determinations.

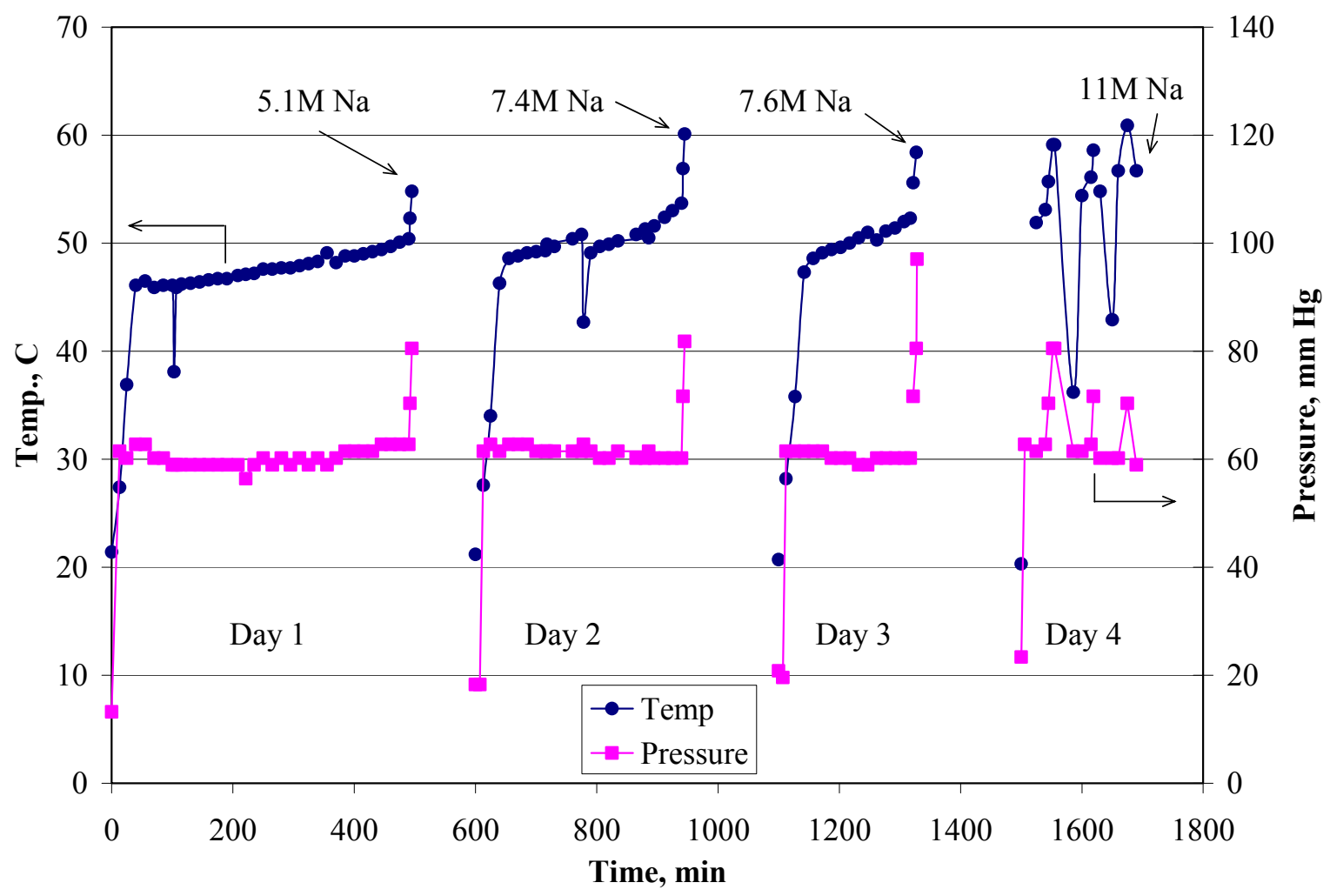

Figure 5. Operating conditions for evaporation of 35:65 blend of AW101/SBS A2 


\subsection{BOILING POINT}

As mentioned previously, boiling points were measured at a range of concentrations and pressures. In addition, estimated boiling points were calculated with an OLI model. For the 35:65 blend, these boiling points are presented in Figure 6. As seen in Figure 6, the experimental boiling points are nominally $5-10^{\circ} \mathrm{C}$ higher than model values for most temperatures and pressures. The reason for the offset between experimental and model results is not clear. In addition, experimental concentrations represent the filtered supernate at room temperature. Precipitation may have occurred during or after boiling point measurements, especially for $11 \mathrm{M}$ Na solutions. This would cause a difference between the actual $\mathrm{Na}$ concentrations and those used in the model, and lead to lower model predictions. Experimental data for the 45:55 blend were similar to those for the 35:65 blend, but were not taken at consistent pressures.

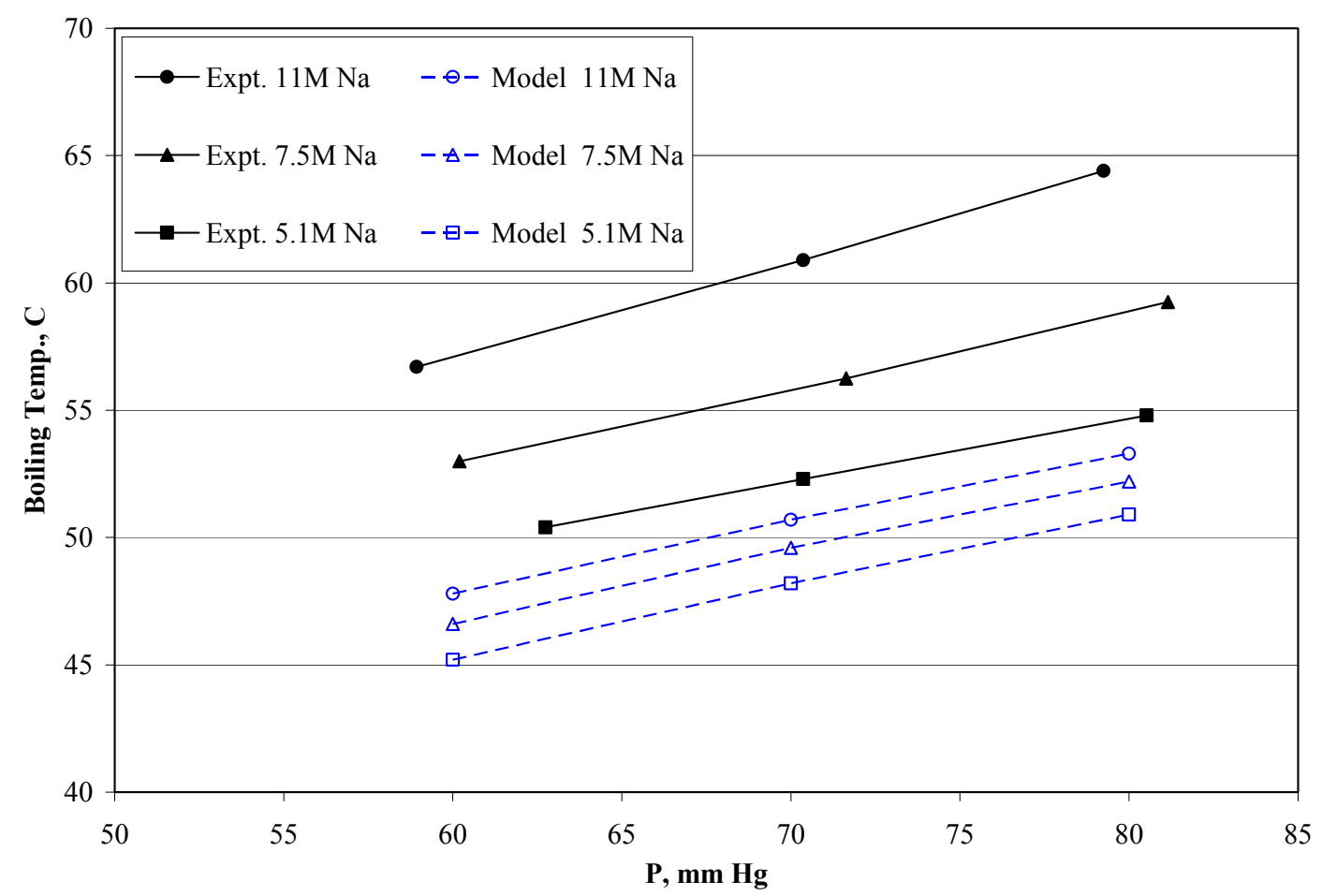

Figure 6. Experimental and model boiling points for 35:65 blend of AW101/SBS A2

\subsection{PRODUCT COMPOSITION}

Composition of concentrate and condensate products of the two evaporated blends are shown in Table 3 through Table 7. Solids analyses are included in the next section. Note that the 45:55 blend condensates in Table 3 were diluted, which increased the detection limits. Condensate samples from the 35:65 blend (Table 6) were not diluted. 
WSRC-TR-2003-00218, REVISION 0

SRT-RPP-2003-00156, REVISION 0

Table 3. Products from Evaporation of 45:55 Blend (AW-101:SBS A2)

\begin{tabular}{|c|c|c|c|c|c|}
\hline \multicolumn{6}{|c|}{ ICP-Emission Spectrometry } \\
\hline & $\begin{array}{l}\text { Feed } \\
\mathrm{mg} / \mathrm{L}\end{array}$ & $\begin{array}{c}\text { Concentrate } \\
\mathrm{mg} / \mathrm{L}\end{array}$ & $\mathbf{C F}$ & $\begin{array}{c}\text { Condensate } \\
\mathrm{mg} / \mathrm{L}\end{array}$ & DF \\
\hline $\mathrm{Ag}$ & $<0.16$ & $<1.60$ & - & $<1.60$ & - \\
\hline $\mathrm{Al}$ & 5910 & 20750 & 3.51 & $<11.4$ & $>518$ \\
\hline B & 449 & 1650 & 3.68 & $<5.60$ & $>80$ \\
\hline $\mathrm{Ba}$ & $<0.38$ & $<3.80$ & - & $<3.80$ & - \\
\hline $\mathrm{Ca}$ & 4.27 & $<4.60$ & - & $<4.60$ & - \\
\hline $\mathrm{Cd}$ & 0.09 & $<0.84$ & - & $<0.84$ & - \\
\hline $\mathrm{Ce}$ & 1.08 & 18.1 & - & 12.9 & - \\
\hline $\mathrm{Cr}$ & 39.35 & 140.5 & 3.57 & $<1.20$ & $>33$ \\
\hline $\mathrm{Cu}$ & 0.71 & 3.23 & - & 2.56 & - \\
\hline $\mathrm{Fe}$ & 0.48 & 3.21 & - & $<0.72$ & - \\
\hline $\mathrm{Gd}$ & $<0.47$ & $<4.68$ & - & $<4.68$ & - \\
\hline $\mathrm{K}$ & 9250 & 32500 & 3.51 & $<188$ & $>49$ \\
\hline $\mathrm{La}$ & $<0.14$ & $<1.44$ & - & $<1.44$ & - \\
\hline $\mathrm{Li}$ & $<0.86$ & $<8.60$ & - & $<8.60$ & - \\
\hline $\mathrm{Mg}$ & $<0.11$ & $<1.06$ & - & $<1.06$ & - \\
\hline $\mathrm{Mn}$ & $<0.02$ & $<0.16$ & - & $<0.16$ & - \\
\hline Mo & 17.25 & 61.9 & 3.59 & $<10.6$ & - \\
\hline $\mathrm{Na}$ & 50550 & 160000 & 3.17 & $<4.40$ & $>1.15 \mathrm{E}+04$ \\
\hline $\mathrm{Na}(\mathrm{M})$ & 2.21 & 6.96 & 3.17 & $<0.0002$ & $>1.1 \mathrm{E}+04$ \\
\hline $\mathrm{Ni}$ & 1.06 & $<2.70$ & - & $<2.70$ & - \\
\hline $\mathrm{P}$ & 61.55 & 212 & 3.44 & $<13.8$ & $>4$ \\
\hline $\mathrm{Pb}$ & 2.16 & 6.98 & 3.24 & $<6.38$ & - \\
\hline $\mathrm{S}$ & 226 & 772.5 & 3.42 & $<27.4$ & $>8$ \\
\hline $\mathrm{Sb}$ & 15.3 & $<75.6$ & - & $<75.6$ & - \\
\hline $\mathrm{Si}$ & 84.75 & 378 & 4.46 & $<3.34$ & $>25$ \\
\hline $\mathrm{Sn}$ & 30.45 & 112.5 & 3.69 & 10.5 & 2.9 \\
\hline $\mathrm{Sr}$ & 1.05 & $<1.52$ & - & $<1.52$ & - \\
\hline $\mathrm{Ti}$ & $<0.15$ & $<1.54$ & - & $<1.54$ & - \\
\hline $\mathrm{U}$ & $<4.54$ & $<45.4$ & - & $<45.4$ & - \\
\hline $\mathrm{V}$ & $<0.04$ & 1.33 & - & 1.11 & - \\
\hline $\mathrm{Zn}$ & 30.45 & 190 & 6.2 & $<0.64$ & $>48$ \\
\hline $\mathrm{Zr}$ & $<0.46$ & $<4.56$ & - & $<4.56$ & - \\
\hline \multicolumn{3}{|l|}{ Average } & 3.45 & \multicolumn{2}{|c|}{ (without $\mathrm{Si}$ and $\mathrm{Zn}$ ) } \\
\hline \multicolumn{3}{|l|}{ St. Dev. } & 0.19 & & \\
\hline
\end{tabular}


In this study, the concentration factor (CF) is defined as the concentration in the concentrate divided by that of the feed. The decontamination factor (DF) is the concentration in the feed divided by that of the condensate. In Table 3, the CFs for silicon ( $\mathrm{Si}$ ) and $\mathrm{Zn}$ are significantly higher than those of other species. This may be due to dissolution of SBS A2 solids in the caustic matrix of the concentrate. In addition, elevated Si in the concentrate may be due to leaching from the glassware. Excluding Si and $\mathrm{Zn}$, the average $\mathrm{CF}$ for the predominant species was 3.45 with a standard deviation of 0.19 . The decontamination factor for sodium was over 10,000. This is consistent with the DFs for anions (in Table 4), which were also greater than 10,000 . DFs for nearly all other components were as high as allowed by instrument detection. However, significantly more cerium in both products than in the feed indicates a likely sample contamination or instrument problem for this element.

Table 4. Anions and Other Evaporation Products of the 45:55 Blend

\begin{tabular}{|c|c|c|c|c|c|}
\hline \multicolumn{6}{|l|}{ IC Anions } \\
\hline & $\begin{array}{l}\text { Feed } \\
\mathrm{mg} / \mathrm{L}\end{array}$ & $\begin{array}{c}\text { Concentrate } \\
\mathrm{mg} / \mathrm{L}\end{array}$ & CF & $\begin{array}{c}\text { Condensate } \\
\mathrm{mg} / \mathrm{L}\end{array}$ & DF \\
\hline Chloride & 2015 & 6475 & 3.2 & $<0.2$ & $>10000$ \\
\hline Fluoride & 382 & 694 & 1.8 & $<0.2$ & $>1900$ \\
\hline Formate & 607 & 543 & 0.9 & $<1$ & $>600$ \\
\hline Nitrate & 36700 & 123000 & 3.4 & $<1$ & $>36700$ \\
\hline Nitrite & 22750 & 78400 & 3.4 & $<1$ & $>22800$ \\
\hline Oxalate & 131 & 323 & 2.5 & $<1$ & $>130$ \\
\hline Phosphate & 66 & 330 & 5.0 & $<1$ & $>66$ \\
\hline Sulfate & 429 & 1355 & 3.2 & $<0.5$ & $>860$ \\
\hline Carbonate & 0.043 & 0.105 & 2.5 & $<0.002$ & $>21$ \\
\hline Total Carbon & 1250 & 3820 & 3.1 & 47 & 27 \\
\hline $\begin{array}{l}\text { Organic } \\
\text { Carbon }\end{array}$ & 822 & 2385 & 2.9 & 28 & 29 \\
\hline $\begin{array}{l}\text { Inorganic } \\
\text { Carbon }\end{array}$ & 418 & 1435 & 3.4 & 19 & 23 \\
\hline & Mol/L & Mol/L & & Mol/L & \\
\hline Total Base & 1.25 & 4.13 & 3.3 & 0.046 & 27 \\
\hline Free $\mathrm{OH}$ & 0.858 & 2.94 & 3.4 & 0.041 & 21 \\
\hline Other Base & 0.375 & 1.1 & 3.0 & $<0.002$ & $>188$ \\
\hline
\end{tabular}


WSRC-TR-2003-00218, REVISION 0

SRT-RPP-2003-00156, REVISION 0

Radioactive components were measured for the products of the 45:55 blend. As shown in Table 5, the CF for gamma emitters was 2.1-3.5, which matches that of the major cations and anions. DF values were limited by instrument detection. Liquid scintillation analyses provided gross alpha and beta values, but these were measured with a screening method. Though quantitative, the method does not yield the accuracy of separation techniques. Analyses for some trace components were not completed due to a related programmatic decision. $^{4}$

Table 5. Radioactive and Trace Metal Components in Evaporation of 45:55 Blend Gamma Pulse Height Analysis

\begin{tabular}{|l|c|c|c|c|c|c|}
\hline & $\begin{array}{c}\text { AW101 IX Effl. } \\
\mu \mathbf{C i} / \mathbf{m L}\end{array}$ & $\begin{array}{c}\mathbf{4 5 : 5 5} \mathbf{B l e n d} \\
\mu \mathbf{C i} / \mathbf{m L}\end{array}$ & $\begin{array}{c}\text { Concentrate } \\
\mu \mathbf{C i} / \mathbf{m L}\end{array}$ & $\mathbf{C F}$ & $\begin{array}{c}\text { Condensate } \\
\mu \mathbf{C i} / \mathbf{m L}\end{array}$ & $\mathbf{D F}$ \\
\hline Co-60 & $1.83 \mathrm{E}-04$ & $8.77 \mathrm{E}-05$ & $2.13 \mathrm{E}-04$ & 2.4 & $<1.23 \mathrm{E}-5$ & $>7.1$ \\
\hline Sb-126 & $2.52 \mathrm{E}-04$ & $1.08 \mathrm{E}-04$ & $3.80 \mathrm{E}-04$ & 3.5 & $<9.38 \mathrm{E}-6$ & $>11.5$ \\
\hline Sn-126 & $2.75 \mathrm{E}-04$ & $1.27 \mathrm{E}-04$ & $2.70 \mathrm{E}-04$ & 2.1 & $<1.59 \mathrm{E}-5$ & $>8.0$ \\
\hline Cs-137 & $2.91 \mathrm{E}-03$ & $1.28 \mathrm{E}-03$ & $4.48 \mathrm{E}-03$ & 3.5 & $<1.22 \mathrm{E}-5$ & $>116$ \\
\hline
\end{tabular}

Liquid Scintillation Analysis

\begin{tabular}{|l|c|c|c|c|c|c|}
\hline & $\mathbf{d p m} / \mathbf{m L}$ & & $\mathbf{d p m} / \mathbf{m L}$ & & $\mathbf{d p m} / \mathbf{m L}$ & \\
\hline Alpha & 759 & $\mathrm{NM}$ & 270 & - & $<46.4$ & - \\
\hline Beta & $1.80 \mathrm{E}+05$ & $\mathrm{NM}$ & $5.45 \mathrm{E}+04$ & - & 461 & $\sim 300$ \\
\hline \multicolumn{6}{|l|}{ Atomic Absorption } \\
\hline \multicolumn{7}{|l|}{} \\
$\mathrm{As}$ & $\mathbf{m g} / \mathbf{L}$ & $\mathbf{m g} / \mathbf{L}$ & $\mathbf{m g} / \mathbf{L}$ & - & $\mathbf{m g} / \mathbf{L}$ & - \\
\hline $\mathrm{Se}$ & 0.49 & 0.17 & 1.48 & - & $<0.025$ & $>6.8$ \\
\hline $\mathrm{Hg}$ & 0.73 & $<0.055$ & 0.45 & - & $<0.025$ & - \\
\hline
\end{tabular}

ICP-Mass Spectrometry

\begin{tabular}{|c|c|c|c|c|c|c|}
\hline Element & $\mathbf{m g} / \mathbf{L}$ & $\mathbf{m g} / \mathbf{L}$ & $\mathbf{m g} / \mathbf{L}$ & & $\mathbf{m g} / \mathbf{L}$ & \\
\hline $\mathrm{Ru}$ & 3 & 1 & 4 & - & $<0.05$ & - \\
\hline $\mathrm{Rh}$ & 4.0 & 2.0 & 7.1 & - & 0.01 & - \\
\hline $\mathrm{Pd}$ & 0.2 & 0.1 & 0.2 & - & $<0.01$ & - \\
\hline $\mathrm{Ta}$ & $<0.1$ & $<0.1$ & $<0.1$ & - & $<0.00001$ & - \\
\hline $\mathrm{Pt}$ & $<0.1$ & $<0.0001$ & $<0.01$ & - & $<0.01$ & - \\
\hline $\mathrm{Pr}$ & $<0.01$ & $<0.0001$ & $<0.0001$ & - & $<0.000003$ & - \\
\hline Isotope & $<0.00006$ & $<0.00002$ & 0.08 & - & 0.001 & - \\
\hline $\mathrm{U}-235$ & $<0.00006$ & 0.02 & $<0.00002$ & - & $<0.000008$ & - \\
\hline $\mathrm{Np}-237$ & 0.01 & 0.03 & 0.05 & - & 0.003 & - \\
\hline $\mathrm{U} / \mathrm{Pu}-238$ & $<0.00006$ & $<0.00002$ & $<0.00002$ & - & $<0.000008$ & - \\
\hline $\begin{array}{l}\text { All other } \\
\text { actinides }\end{array}$ & & \multicolumn{7}{|l}{} \\
\hline
\end{tabular}


WSRC-TR-2003-00218, REVISION 0 SRT-RPP-2003-00156, REVISION 0

Table 6. Products from Evaporation of 35:65 Blend (AW-101:SBS A2)

\begin{tabular}{|c|c|c|c|c|c|}
\hline \multicolumn{6}{|c|}{ ICP-Emission Spectrometry } \\
\hline & $\begin{array}{l}\text { Feed } \\
\mathrm{mg} / \mathrm{L}\end{array}$ & $\begin{array}{c}\text { Concentrate } \\
\mathrm{mg} / \mathrm{L}\end{array}$ & CF & $\begin{array}{c}\text { Condensate } \\
\mathrm{mg} / \mathrm{L}\end{array}$ & DF \\
\hline $\mathrm{Ag}$ & $<0.16$ & 0.21 & - & $<0.01$ & - \\
\hline $\mathrm{Al}$ & 4100 & 27350 & 6.7 & 0.08 & 52600 \\
\hline B & 526 & 2300 & 4.4 & 0.14 & 3700 \\
\hline $\mathrm{Ba}$ & $<0.38$ & 0.383 & - & $<0.02$ & - \\
\hline $\mathrm{Ca}$ & 5.19 & 11.9 & - & $<0.03$ & - \\
\hline $\mathrm{Cd}$ & $<0.08$ & 1.27 & - & $<0.01$ & - \\
\hline $\mathrm{Ce}$ & 2.41 & 3.56 & - & 0.1 & - \\
\hline $\mathrm{Cr}$ & 39.9 & 166 & 4.1 & $<0.01$ & $>5700$ \\
\hline $\mathrm{Cu}$ & 0.54 & 1.42 & - & 0.02 & - \\
\hline $\mathrm{Fe}$ & 0.14 & 4.86 & - & $<0.002$ & - \\
\hline $\mathrm{Gd}$ & $<0.47$ & $<0.47$ & - & $<0.03$ & - \\
\hline $\mathrm{K}$ & 6035 & 34400 & 5.7 & NM & - \\
\hline $\mathrm{La}$ & 0.42 & 0.53 & - & 0.01 & - \\
\hline $\mathrm{Li}$ & 1.35 & 3.92 & - & $<0.03$ & - \\
\hline $\mathrm{Mg}$ & $<0.11$ & $<0.11$ & - & $<0.02$ & - \\
\hline $\mathrm{Mn}$ & $<0.02$ & $<0.02$ & - & $<0.001$ & - \\
\hline Mo & 9.81 & 53.2 & 5.4 & $<0.06$ & $>164$ \\
\hline $\mathrm{Na}$ & 48900 & 175000 & 3.6 & 0.28 & 176000 \\
\hline $\mathrm{Na}(\mathrm{M})$ & 2.13 & 7.61 & 3.6 & 0.000012 & 176000 \\
\hline $\mathrm{Ni}$ & 1.30 & 3.52 & - & $<0.02$ & - \\
\hline $\mathrm{P}$ & 47.8 & 225 & 4.7 & $<0.08$ & $>630$ \\
\hline $\mathrm{Pb}$ & $<0.67$ & 9.53 & - & $<0.04$ & - \\
\hline S & 217 & 928 & 4.3 & 0.16 & 1400 \\
\hline $\mathrm{Sb}$ & 11.9 & 50.8 & 4.3 & $<0.42$ & $>28$ \\
\hline $\mathrm{Si}$ & 71.8 & 233 & 3.2 & 1.31 & 22 \\
\hline $\mathrm{Sn}$ & 22.2 & 96.3 & 4.3 & 0.07 & 317 \\
\hline $\mathrm{Sr}$ & 1.35 & 0.02 & - & $<0.001$ & - \\
\hline $\mathrm{Ti}$ & $<0.15$ & 0.53 & - & $<0.008$ & - \\
\hline $\mathrm{U}$ & 5.47 & 8.31 & - & 0.26 & - \\
\hline $\mathrm{V}$ & NM & 7.05 & - & 0.009 & - \\
\hline $\mathrm{Zn}$ & 34.2 & 291 & 8.5 & 0.005 & 6840 \\
\hline $\mathrm{Zr}$ & $<0.46$ & 2.01 & - & $<0.03$ & - \\
\hline
\end{tabular}

$\mathrm{NM}=$ Not Measured 
WSRC-TR-2003-00218, REVISION 0

SRT-RPP-2003-00156, REVISION 0

Table 7. More Products of Evaporation of 35:65 Blend

\begin{tabular}{|l|c|c|c|c|}
\hline IC Anions & $\begin{array}{c}\text { Feed } \\
\mathbf{m g} / \mathbf{L}\end{array}$ & $\begin{array}{c}\text { Concentrate } \\
\mathbf{m g} / \mathbf{L}\end{array}$ & $\mathbf{C F}$ & $\begin{array}{c}\text { Condensate } \\
\mathbf{m g} / \mathbf{L}\end{array}$ \\
\hline Chloride & 1840 & 10900 & 5.9 & $<2$ \\
\hline Fluoride & 744 & 272 & 0.4 & $<2$ \\
\hline Formate & 323 & 2400 & 7.4 & $<10$ \\
\hline Nitrate & 25000 & 169000 & 6.8 & $<10$ \\
\hline Nitrite & 16150 & 104400 & 6.5 & $<10$ \\
\hline Oxalate & 86 & 185 & 2.2 & $<10$ \\
\hline Phosphate & 96 & 250 & 2.6 & $<10$ \\
\hline Sulfate & 400 & 1405 & 3.5 & $<5$ \\
\hline \multicolumn{5}{|l}{} \\
\hline Total Base & 0.888 & 4.16 & 4.7 & $\mathbf{M o l} / \mathbf{L}$ \\
\hline Free OH & 0.58 & 2.73 & 4.7 & 0.056 \\
\hline Other Base & 0.15 & 1.18 & 7.6 & $<0.02$ \\
\hline
\end{tabular}

\subsection{SOLIDS}

The solids found in AW-101/SBS A2 concentrate were identified by XRD. Four filter cake samples from different blend ratios and concentrations were analyzed. The solids found in all four samples, in order of decreasing concentration, were: $\mathrm{SiO}_{2}$ (quartz), $\mathrm{NaF}, \mathrm{NaNO}_{3}$, $\mathrm{K}_{2} \mathrm{NaAlF}_{6}, \mathrm{Na}_{2} \mathrm{CO}_{3} \bullet \mathrm{H}_{2} \mathrm{O}, \mathrm{Fe}_{2} \mathrm{O}_{3}$, and $\mathrm{ZrSiO}_{4}$. In addition, $\mathrm{CaF}_{2}, \mathrm{Na}_{2} \mathrm{Ca}\left(\mathrm{CO}_{3}\right)_{2} \bullet 2 \mathrm{H}_{2} \mathrm{O}$, and $\mathrm{PuO}_{2}$ were each detected at trace levels in two samples. Since mass spectrometry showed very low levels of plutonium in feed and concentrate solutions, the detection of $\mathrm{PuO}_{2}$ is likely due to cross-contamination during laboratory handling.

Table 8 and Table 9 contain data for the weight percent solids, specific gravity, and sodium concentration of the feed and a range of concentrate samples. The data follows expected trends, except the insoluble solids values for $5.1 \mathrm{M}$ and $8.7 \mathrm{M} \mathrm{Na}$ concentrate. In these cases, the samples may not have been representative of the well-mixed concentrate. More likely, the low values are due to analytical variability because weight percent insoluble solids is determined by the difference of two large numbers - wt. \% total solids and wt. \% solids in filtrate. Nevertheless, as shown in Figure 7, the data for the 35:65 blend indicates that precipitation begins between 8.7 and $10.4 \mathrm{M} \mathrm{Na}$. 
WSRC-TR-2003-00218, REVISION 0

SRT-RPP-2003-00156, REVISION 0

Table 8. Solids and Sodium Concentrations during Evaporation of 35:65 Blend

\begin{tabular}{|c|c|c|c|c|c|c|c|}
\hline & Feed & \multicolumn{7}{|c|}{ Concentrate } \\
\hline \multicolumn{2}{|c|}{} & \multicolumn{7}{|c|}{ Target } & & Sat'd \\
\hline $\mathrm{Na}, \mathrm{M}$ & $2.13^{*}$ & 5.13 & 7.39 & $7.61^{*}$ & 8.74 & 10.0 & 11.0 \\
\hline $\begin{array}{c}\text { Specific } \\
\text { Gravity }\end{array}$ & $1.08^{*}$ & $\mathrm{NM}$ & $\mathrm{NM}$ & $1.38^{*}$ & $\mathrm{NM}$ & $\mathrm{NM}$ & $\mathrm{NM}$ \\
\hline $\begin{array}{c}\text { Insoluble } \\
\text { Solids, wt\% }\end{array}$ & 0.39 & 0.12 & 0.92 & $1.25^{*}$ & 0.7 & $4.4^{*}$ & 10.4 \\
\hline $\begin{array}{c}\text { Total Solids, } \\
\text { wt\% }\end{array}$ & $11.8^{*}$ & 31.4 & 42.2 & $43.5^{*}$ & 49.4 & $54.5^{*}$ & 59.3 \\
\hline
\end{tabular}

*Average of two samples. NM $=$ Not measured

Table 9. Solids and Sodium Concentrations during Evaporation of 45:55 Blend

\begin{tabular}{|c|c|c|c|c|c|}
\hline & \multicolumn{2}{|c|}{ Feed } & \multicolumn{4}{c|}{ Concentrate } & Condensate \\
\hline \multicolumn{2}{|c|}{} & \multicolumn{2}{|c|}{ Target } & Sat'd & \\
\hline Na, M & 2.20 & 5.09 & 6.96 & 10.4 & $<0.0002$ \\
\hline Specific Gravity & 1.10 & NM & 1.36 & 1.57 & 0.993 \\
\hline $\begin{array}{c}\text { Insoluble } \\
\text { Solids, wt.\% }\end{array}$ & 0.20 & 0.36 & 0.67 & 5.73 & None visible \\
\hline Total Solids, wt.\% & 15.7 & 36.8 & 47.2 & 58.8 & 0.20 \\
\hline
\end{tabular}

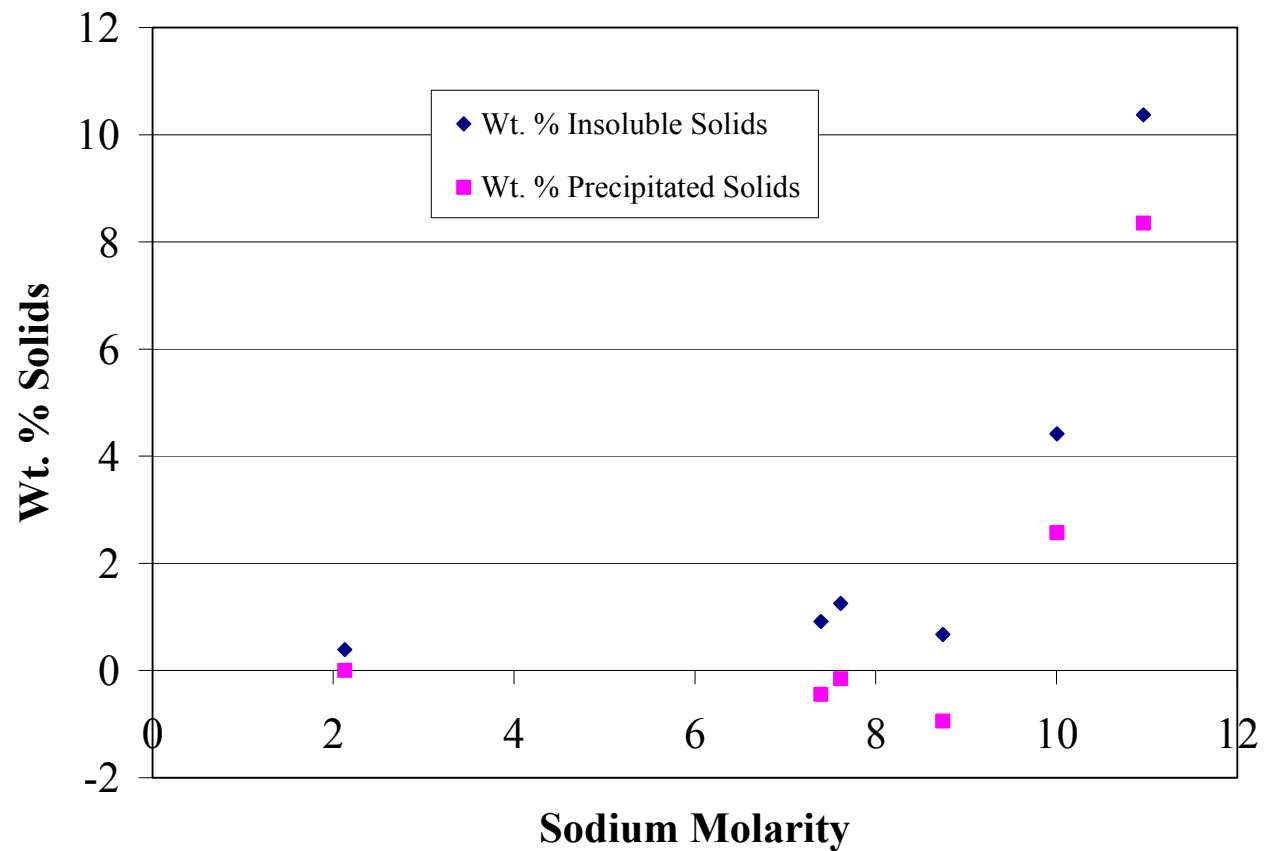

Figure 7. Wt. \% Total and Insoluble Solids for 35:65 Blend of AW-101/SBS A2 


\subsection{RHEOLOGY}

The rheology was measured with a Haake RV20/M5 rheometer. An MV1 concentric cylinder geometry head was used for the measurement, due to solids in the feed material. Prior to analyzing the sample, the MV1 bob was inspected for damage, and installed onto the rheometer after passing the visual inspection. A flow curve program reflecting the requirements in the RPP-WTP physical and rheological procedure was used. Per RPP-WTP requirements, the rheometer functionality must be checked using a NIST-traceable Newtonian oil standard and the measured viscosity must be within $+/-10 \%$ of the standard. A N35 oil standard was used and the resulting viscosity was within the stated requirements.

The two AW-101 concentrated samples were analyzed at $25^{\circ} \mathrm{C}$, in duplicate. Both samples behaved liked Newtonian fluids and a representative flow curve can be seen in Figure 8. No settling issues were observed in the flow curve measurements. The average viscosities of the samples are listed below:

45:55 Blend of AW101/SBS A2 at 7.0M Na $=7.1 \mathrm{cP}$ (or mPa-sec) $35: 65$ Blend of AW101/SBS A2 at 7.6M Na $=8.7 \mathrm{cP}$ (or mPa-sec)

For twelve different Envelope A simulants ${ }^{1}$, the measured viscosity at $7 \mathrm{M} \mathrm{Na}$ had a median value of $3.5 \mathrm{cP}$ and a high of $6 \mathrm{cP}$. The AW101/SBS A2 value of $7.1 \mathrm{cP}$ is twice as large as the median simulant value. Similarly, at $7.6 \mathrm{M} \mathrm{Na}$, the simulant viscosity median was about $4.3 \mathrm{cP}$. The AW101/SBS A2 value of $8.7 \mathrm{cP}$ is twice as large. The reason for higher viscosities in the real waste material is not clear. Determining the cause for these differences is outside the scope of this task. However, total organic carbon (TOC) levels may have contributed to higher viscosity values. The 45:55 blend, for example, had $2400 \mathrm{mg} \mathrm{TOC} / \mathrm{L}$. It is important to note that the viscosities of concentrated AW-101 solutions in this study, as well as those of the simulants in the earlier study, all fall well within the expected range of 0.4 to $15 \mathrm{cP}$, the current bounding conditions for the WTP. ${ }^{6}$

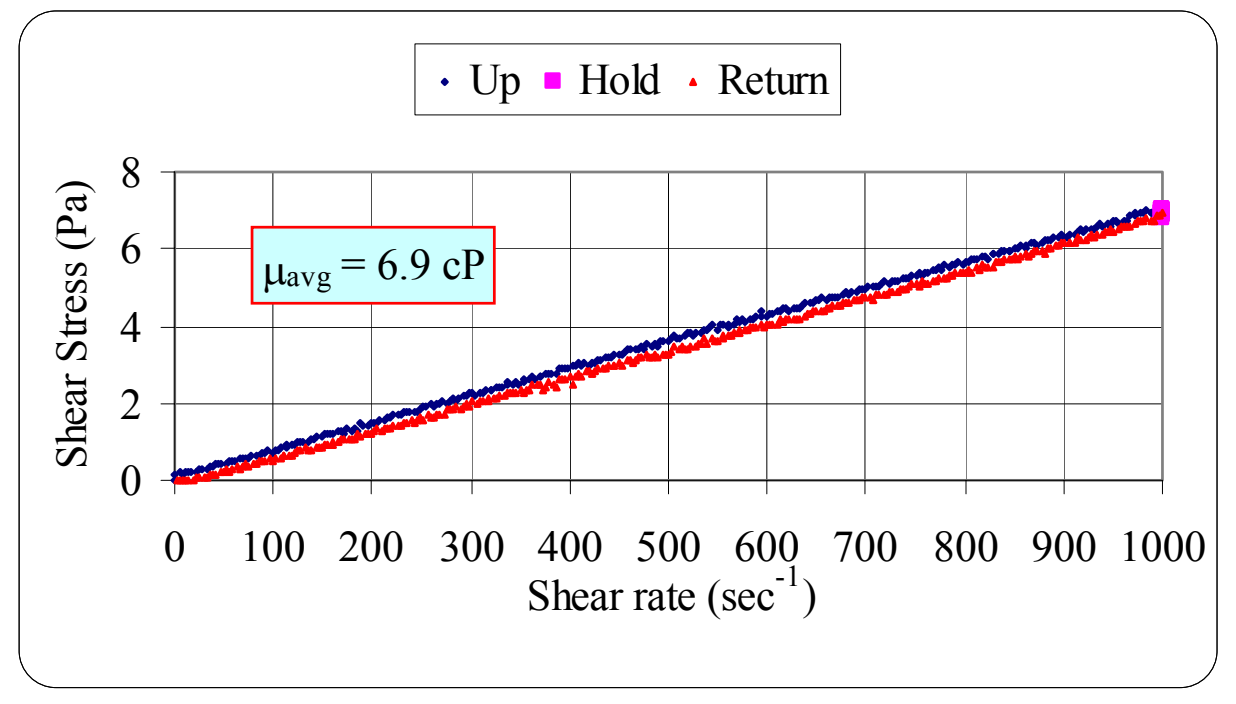

Figure 8. Flow Curve for 45:55 Blend of AW-101 to SBS A2 at 7 M sodium 


\subsection{HEAT CAPACITY}

Heat capacity of concentrates was measured with an Instrument Specialist, Inc. DSC 500 with an indium reference. Both water and sapphire $\left(\mathrm{Al}_{2} \mathrm{O}_{3}\right.$ - aluminum oxide $)$ standards were tested to ensure equipment accuracy. The instrument is a Differential Scanning Calorimeter operated according to the applicable ASTM Standard ${ }^{9}$. Reported results are the average of two samples and represent the heat capacity at $50^{\circ} \mathrm{C}$. For Blend 1, the concentrate supernate and slurry values were 0.78 and $0.81 \mathrm{cal} / \mathrm{g}{ }^{\circ} \mathrm{C}$, respectively (i.e., 3.3 and $3.4 \mathrm{~J} / \mathrm{g}{ }^{\circ} \mathrm{C}$ ). For Blend 2, the supernate and slurry values were 0.79 and $0.76 \mathrm{cal} / \mathrm{g}{ }^{\circ} \mathrm{C}$, respectively (i.e., 3.3 and $3.2 \mathrm{~J} / \mathrm{g}{ }^{\circ} \mathrm{C}$ ). In both cases, the presence of insoluble solids had no significant effect on heat capacity.

Heat capacities for AW-101/SBS A2 concentrates are similar to that of the as-received AN-107 sample (9.0 M Na, $49.5 \mathrm{wt} . \%$ total solids, $0.48 \%$ insoluble solids), which had a heat capacity of $0.82 \mathrm{~J} / \mathrm{g}^{\circ} \mathrm{C}^{10}$. However, the heat capacities observed for Envelope A simulants were consistently $0.6 \mathrm{cal} / \mathrm{g}^{\circ} \mathrm{C}$ (or slightly less) for both $6 \mathrm{M}$ and $8 \mathrm{M} \mathrm{Na}$ concentrates. 


\subsection{CONCLUSIONS}

Blended solutions of pretreated Hanford Tank 241-AW-101 and simulated SBS A2 recycle boiled at expected RPP-WTP flowsheet conditions: $60 \mathrm{~mm} \mathrm{Hg}$ and $50^{\circ} \mathrm{C}$. As expected, boiling point increased with concentration. Specifically, the 35:65 blend of AW-101 to SBS $\mathrm{A} 2$ at $7.5 \mathrm{M}$ sodium had boiling points of $53^{\circ} \mathrm{C}$ at $60 \mathrm{~mm} \mathrm{Hg}$ and $59^{\circ} \mathrm{C}$ at $80 \mathrm{~mm} \mathrm{Hg}$. These were $6-7^{\circ} \mathrm{C}$ higher than those estimated by an OLI model.

Precipitation of solids in the AW-101/SBS A2 matrix began between $8.7 \mathrm{M}$ and $10.4 \mathrm{M}$ sodium. No problematic or excessive solids were observed. Therefore, SBS recycles are not expected to have any adverse effect on the evaporation process in the RPP-WTP.

In general, foaming did not occur. However, foaming was observed during post-saturation boiling of the 45:55 blend of AW-101 and SBS A2. (The post-saturation concentrate included 10.4 M Na, 59 wt.\% total solids, and 5.7 wt.\% suspended solids.) Foaming was not observed for the 35:65 blend, even after saturation (i.e., 11.0 M Na, 10.4 wt.\% suspended solids, and 59 wt. $\%$ total solids).

The target concentrates of AW-101/SBS A2 (i.e., $7 \mathrm{M} \mathrm{Na}$ for the 45:55 blend and 7.6 M Na for the 35:55 blend) had the following physical properties: viscosity (7-9 cP), heat capacity $\left(0.8 \mathrm{cal}^{\circ} \mathrm{C}\right)$, and specific gravity (1.36-1.38). These values are all higher than those observed for Envelope A simulants. ${ }^{1}$ 
WSRC-TR-2003-00218, REVISION 0

SRT-RPP-2003-00156, REVISION 0

This page intentionally left blank. 


\subsection{FUTURE WORK}

Future evaporation studies with Hanford samples will include vapor fluxes closer to design conditions. For the evaporation of AN104, a heating coil was added inside the evaporator that will yield a vapor flux rate that is $20 \%$ of the maximum design value. This five-fold increase should allow a more complete answer on the occurrence of foaming and effectiveness of antifoam treatments. 
WSRC-TR-2003-00218, REVISION 0

SRT-RPP-2003-00156, REVISION 0

This page intentionally left blank. 
WSRC-TR-2003-00218, REVISION 0

SRT-RPP-2003-00156, REVISION 0

\subsection{REFERENCES}

1. Josephs, J.E., M.E. Stone, T.B. Calloway, R.E. Eibling, C.D. Barnes, and E.K. Hansen, "Treated LAW Feed Evaporation: Physical Properties and Solubility Determination," WSRC-TR- 2003-00119, Westinghouse Savannah River Co., Aiken, SC (March 2003).

2. N. Hassan, Task Technical and Quality Assurance Plan for Cesium and Technetium Ion Exchange Using Tank 241-AW-101 Sample, WSRC-TR-2001-00545, SRT-RPP-200100207, (July 2002).

3. Longwell, R.L., Email attachment, Unpublished Model Results from Nov. 19, 2002, (July 2003).

4. Total volume of AW-101 material in evaporator feed was reduced from $\sim 15 \mathrm{~L}$ to $\sim 3 \mathrm{~L}$ due to related programmatic decision: Deletion of Remaining $A W-101$ Vitrification and Tc Removal Scope, BCR No. 03-04, March 27, 2003.

5. Qureshi, Z. H., "Scaling Parameters for the Pilot-Scale Evaporator Test Facility," Aug. 22, 2002, to be published in the RPP-WTP Pilot-Plant Evaporation Report.

6. Poloski, A., H. Smith, G. Smith, and B. Calloway, "Interim Report: Development of LAW and HLW Vitrification Physical Property Bounding Conditions and Simulant Verification Criteria,” WTP-RPT-075, Rev. 0, March 2003.

7. Longwell, R.L., Treated Feed: Evaporation of Tank AW101 Waste with Simulant Recycle, 24590-PTF-TSP-RT-02-007, Rev. 0, Bechtel National Corporation, Richland, WA (2002).

8. Crawford, C.L. and T.B. Calloway, Jr., "Task Technical and Quality Assurance Plan for Pretreated Feed: Evaporation of Tank AW-101 Waste with Simulant Recycle," Westinghouse Savannah River Company, Aiken, SC 29808, (Nov. 2002).

9. Hassan, N.M., C.A. Nash, and K. Adu-Wusu, "Multiple Ion Exchange Column Runs for Cesium and Technetium Removal from AW-101 Waste Sample (U)," WSRC-TR-200300098 (SRT-RPP-2003-00026), Rev. 0, Westinghouse Savannah River Co., Aiken, SC (October 2003).

10. ASTM E1269-01, Standard Test Method for Determining Specific Heat Capacity by Differential Scanning Calorimetry, American Society of Testing and Materials (2001).

11. Martin, K.B., C.J. Coleman, M.S. Hay, “Compositing, Homogenization, and Characterization of Samples from Hanford Tank 241-AN-107," WSRC-TR-2003-00210, Rev. 0, Westinghouse Savannah River Co., Aiken, SC (October 2003). 
WSRC-TR-2003-00218, REVISION 0

SRT-RPP-2003-00156, REVISION 0

This page intentionally left blank. 
WSRC-TR-2003-00218, REVISION 0

SRT-RPP-2003-00156, REVISION 0

\section{APPENDIX A. METALS DATA}

Table A- 1. Metals in Feed and Condensate for 35:65 Blend of AW-101/SBS A2

\begin{tabular}{|c|c|c|c|c|c|c|}
\hline & \multicolumn{3}{|c|}{ Feed (35:65 Blend) } & \multicolumn{3}{|c|}{ Condensate } \\
\hline Sample\# & 193464 & 193465 & Avg. & 193466 & 193467 & Avg. \\
\hline Analyte & $\mathrm{mg} / \mathrm{L}$ & $\mathrm{mg} / \mathrm{L}$ & $\mathrm{mg} / \mathrm{L}$ & $\mathrm{mg} / \mathrm{L}$ & $\mathrm{mg} / \mathrm{L}$ & $\mathrm{mg} / \mathrm{L}$ \\
\hline $\mathrm{Ag}$ & $<0.160$ & $<0.160$ & $<0.160$ & $<0.009$ & $<0.009$ & $<0.009$ \\
\hline $\mathrm{Al}$ & 4140 & 4060 & 4100 & 0.1 & 0.056 & 0.078 \\
\hline $\mathrm{B}$ & 522 & 530 & 526 & 0.1 & 0.141 & 0.143 \\
\hline $\mathrm{Ba}$ & $<0.380$ & $<0.380$ & $<0.380$ & $<0.021$ & $<0.021$ & $<0.021$ \\
\hline $\mathrm{Ca}$ & 5.15 & 5.23 & 5.19 & $<0.025$ & $<0.025$ & $<0.025$ \\
\hline $\mathrm{Cd}$ & $<0.084$ & $<0.084$ & $<0.084$ & $<0.005$ & $<0.005$ & $<0.005$ \\
\hline $\mathrm{Ce}$ & 2.25 & 2.56 & 2.41 & 0.139 & $<0.030$ & 0.085 \\
\hline $\mathrm{Cr}$ & 39.7 & 40.1 & 39.9 & $<0.007$ & $<0.007$ & $<0.007$ \\
\hline $\mathrm{Cu}$ & 0.529 & 0.54 & 0.535 & 0.018 & 0.014 & 0.016 \\
\hline $\mathrm{Fe}$ & 0.136 & 0.14 & 0.138 & $<0.002$ & $<0.002$ & $<0.002$ \\
\hline $\mathrm{Gd}$ & $<0.468$ & $<0.468$ & $<0.468$ & $<0.026$ & $<0.026$ & $<0.026$ \\
\hline $\mathrm{K}$ & 5990 & 6080 & 6035 & NM & $\mathrm{NM}$ & NM \\
\hline $\mathrm{La}$ & 0.383 & 0.456 & 0.420 & 0.013 & $<0.008$ & 0.010 \\
\hline $\mathrm{Li}$ & 1.26 & 1.44 & 1.35 & $<0.047$ & $<0.002$ & $<0.002$ \\
\hline $\mathrm{Mg}$ & $<0.106$ & $<0.106$ & $<0.106$ & $<0.006$ & $<0.026$ & $<0.026$ \\
\hline $\mathrm{Mn}$ & $<0.016$ & $<0.016$ & $<0.016$ & $<0.001$ & $<0.001$ & $<0.001$ \\
\hline Mo & 10.3 & 9.32 & 9.81 & $<0.058$ & $<0.058$ & $<0.058$ \\
\hline $\mathrm{Na}$ & 51400 & 46400 & 48900 & 0.341 & 0.214 & 0.278 \\
\hline $\mathrm{Ni}$ & 1.27 & 1.33 & 1.30 & $<0.015$ & $<0.015$ & $<0.015$ \\
\hline $\mathrm{P}$ & 47.5 & 48.1 & 47.800 & $<0.076$ & $<0.076$ & $<0.076$ \\
\hline $\mathrm{Pb}$ & 0.703 & $<0.638$ & $<0.671$ & $<0.035$ & $<0.035$ & $<0.035$ \\
\hline $\mathrm{S}$ & 216 & 218 & 217 & 0.2 & $<0.151$ & 0.155 \\
\hline $\mathrm{Sb}$ & 11.8 & 12 & 11.9 & $<0.416$ & $<0.416$ & $<0.416$ \\
\hline $\mathrm{Si}$ & 71.4 & 72.2 & 71.8 & 1.4 & 1.24 & 1.305 \\
\hline $\mathrm{Sn}$ & 21.1 & 23.3 & 22.2 & 0.1 & $<0.050$ & 0.1 \\
\hline $\mathrm{Sr}$ & 1.35 & 1.35 & 1.35 & $<0.001$ & $<0.001$ & $<0.001$ \\
\hline $\mathrm{Ti}$ & $<0.154$ & $<0.154$ & $<0.154$ & $<0.008$ & $<0.008$ & $<0.008$ \\
\hline $\mathrm{U}$ & 5.46 & 5.47 & 5.47 & 0.3 & $<0.250$ & 0.257 \\
\hline $\mathrm{V}$ & NM & NM & NM & 0.0 & 0.008 & 0.009 \\
\hline $\mathrm{Zn}$ & 34.1 & 34.2 & 34.2 & 0.0 & $<0.004$ & 0.005 \\
\hline $\mathrm{Zr}$ & $<0.456$ & $<0.456$ & $<0.456$ & $<0.025$ & $<0.025$ & $<0.025$ \\
\hline
\end{tabular}


WSRC-TR-2003-00218, REVISION 0

SRT-RPP-2003-00156, REVISION 0

Table A- 2. Metals in Concentrate Solutions from 35:65 Blend of AW-101/SBS A2

\begin{tabular}{|c|c|c|c|c|c|c|c|c|}
\hline \multirow[b]{2}{*}{ Sample\# } & \multirow{2}{*}{$\begin{array}{c}\text { Conc. } \\
5 \text { M Na } \\
193472 \\
\end{array}$} & \multirow{2}{*}{\begin{tabular}{|c|} 
Conc. \\
$7 \mathrm{M} \mathrm{Na}$ \\
193475 \\
\end{tabular}} & \multicolumn{3}{|c|}{ Concentrate } & \multirow{2}{*}{ 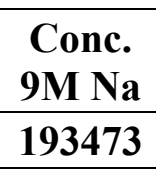 } & \multirow{2}{*}{$\begin{array}{c}\begin{array}{c}\text { Conc. } \\
10 M\end{array} \\
193474 \\
\end{array}$} & \multirow{2}{*}{$\begin{array}{c}\text { Conc. } \\
\text { Sat'd } \\
193476 \\
\end{array}$} \\
\hline & & & 193470 & 193471 & Avg. & & & \\
\hline Analyte & $\mathrm{mg} / \mathrm{L}$ & $\mathrm{mg} / \mathrm{L}$ & $\mathrm{mg} / \mathrm{L}$ & $\mathrm{mg} / \mathrm{L}$ & $\mathrm{mg} / \mathrm{L}$ & $\mathrm{mg} / \mathrm{L}$ & $\mathrm{mg} / \mathrm{L}$ & $\mathrm{mg} / \mathrm{L}$ \\
\hline $\mathrm{Ag}$ & $<0.160$ & $<0.160$ & 0.175 & 0.243 & 0.21 & 0.34 & 0.198 & 0.514 \\
\hline $\mathrm{Al}$ & 15000 & 28800 & 26600 & 28100 & 27350 & 19700 & 23400 & 27400 \\
\hline B & 1620 & 2080 & 2200 & 2400 & 2300 & 2590 & 2880 & 3840 \\
\hline $\mathrm{Ba}$ & $<0.380$ & $<0.380$ & 0.387 & $<0.380$ & 0.383 & 0.459 & 0.506 & 0.848 \\
\hline $\mathrm{Ca}$ & 6.92 & 7.65 & 11.5 & 12.3 & 11.9 & 11 & 16.2 & 6.78 \\
\hline $\mathrm{Cd}$ & 0.564 & 1.07 & 1.25 & 1.28 & 1.27 & 1.48 & 1.29 & 1.24 \\
\hline $\mathrm{Ce}$ & 1.76 & $<0.540$ & 3.28 & 3.83 & 3.56 & 5.1 & 3.76 & 7.27 \\
\hline $\mathrm{Cr}$ & 121 & 154 & 166 & 165 & 165.5 & 184 & 201 & 235 \\
\hline $\mathrm{Cu}$ & 1.88 & 2.91 & 1.35 & 1.48 & 1.42 & 2.99 & 3.32 & 3.81 \\
\hline $\mathrm{Fe}$ & 8.59 & 22.7 & 4.95 & 4.76 & 4.86 & 22 & 13.3 & 11.8 \\
\hline $\mathrm{Gd}$ & $<0.468$ & $<0.468$ & $<0.468$ & $<0.468$ & $<0.468$ & 0.606 & $<0.468$ & 0.888 \\
\hline $\mathrm{K}$ & 25400 & 41100 & 33000 & 35800 & 34400 & 39400 & 46000 & 49000 \\
\hline $\mathrm{La}$ & 0.173 & $<0.144$ & 0.481 & 0.57 & 0.53 & 0.813 & 0.601 & 1.14 \\
\hline $\mathrm{Li}$ & 2.71 & 2.52 & 3.43 & 4.4 & 3.92 & 4.59 & 4.87 & 8.09 \\
\hline $\mathrm{Mg}$ & $<0.106$ & $<0.106$ & $<0.106$ & $<0.106$ & $<0.106$ & $<0.106$ & 0.15 & $<0.106$ \\
\hline $\mathrm{Mn}$ & $<0.016$ & $<0.016$ & $<0.016$ & $<0.016$ & $<0.016$ & $<0.016$ & $<0.016$ & $<0.016$ \\
\hline Mo & 37.1 & 49.6 & 54.3 & 52 & 53.2 & 52 & 63.7 & 67.4 \\
\hline $\mathrm{Na}$ & 118000 & 170000 & 174000 & 176000 & 175000 & 201000 & 230000 & 252000 \\
\hline $\mathrm{Ni}$ & 4.05 & 3.05 & 3.42 & 3.62 & 3.52 & 4.52 & 4.48 & 4.79 \\
\hline $\mathrm{P}$ & 151 & 215 & 227 & 223 & 225 & 204 & 298 & 328 \\
\hline $\mathrm{Pb}$ & 12.4 & 23.4 & 10.8 & 8.26 & 9.53 & 32.9 & 38.4 & 54.7 \\
\hline $\mathrm{S}$ & 665 & 914 & 915 & 940 & 928 & 501 & 489 & 517 \\
\hline $\mathrm{Sb}$ & 35.5 & 46.5 & 50.8 & 50.8 & 50.8 & 56.4 & 67.7 & 81.9 \\
\hline $\mathrm{Si}$ & 311 & 293 & 226 & 239 & 233 & 220 & 247 & 291 \\
\hline $\mathrm{Sn}$ & 61.6 & 88.7 & 98.2 & 94.3 & 96.3 & 100 & 116 & 129 \\
\hline $\mathrm{Sr}$ & $<0.020$ & $<0.020$ & 0.026 & $<0.020$ & 0.023 & 3.56 & 4.33 & 2.97 \\
\hline $\mathrm{Ti}$ & 0.369 & 1.1 & 0.527 & 0.528 & 0.53 & 1.39 & 2.01 & 1.62 \\
\hline $\mathrm{U}$ & 6.54 & $<4.54$ & 6.99 & 9.62 & 8.31 & 11.7 & 9.49 & 19.9 \\
\hline $\mathrm{V}$ & 4.65 & 6.91 & 7.02 & 7.08 & 7.05 & NM & NM & NM \\
\hline $\mathrm{Zn}$ & 148 & 249 & 279 & 303 & 291 & 339 & 388 & 528 \\
\hline $\mathrm{Zr}$ & 1.1 & 4.24 & 1.98 & 2.03 & 2.01 & 5.47 & 7.7 & 9.58 \\
\hline
\end{tabular}

